ICTD African Tax Administration Paper 21

\section{Tax Amnesties in Africa: An Analysis of the Voluntary Disclosure Programme in Uganda}

Solomon Rukundo

December 2020 
Tax Amnesties in Africa: An Analysis of the Voluntary Disclosure Programme in Uganda

Solomon Rukundo

ICTD African Tax Administration Paper 21

First published by the Institute of Development Studies in December 2020

(C) Institute of Development Studies 2020

ISBN: 978-1-78118-748-7

DOI: $10.19088 /$ ICTD.2020.005

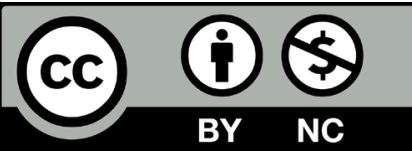

This is an Open Access paper distributed under the terms of the Creative Commons Attribution Non Commercial 4.0 International license, which permits downloading and sharing provided the original authors and source are credited - but the work is not used for commercial purposes. http://creativecommons.org/licenses/by-nc/4.0/legalcode

Available from:

The International Centre for Tax and Development at the Institute of Development Studies, Brighton BN1 9RE, UK

Tel: +44(0) 1273606261

Email: info@ictd.ac

Web: www.ictd.ac/publication

Twitter: @ICTDTax

Facebook: www.facebook.com/ICTDtax

IDS is a charitable company limited by guarantee and registered in England

Charity Registration Number 306371

Charitable Company Number 877338 


\title{
Tax Amnesties in Africa: An Analysis of the Voluntary Disclosure Programme in Uganda
}

\author{
Solomon Rukundo
}

\section{Summary}

Tax amnesties have taken centre stage as a compliance tool in recent years. The OECD estimates that since 2009 tax amnesties in 40 jurisdictions have resulted in the collection of an additional $€ 102$ billion in tax revenue. A number of African countries have introduced tax amnesties in the last decade, including Nigeria, Namibia, South Africa and Tanzania. Despite their global popularity, the efficacy of tax amnesties as a tax compliance tool remains in doubt. The revenue is often below expectations, and it probably could have been raised through effective use of regular enforcement measures. It is also argued that tax amnesties might incentivise non-compliance - taxpayers may engage in non-compliance in the hope of benefiting from an amnesty.

This paper examines the administration of tax amnesties in various jurisdictions around the world, including the United States, Australia, Canada, Kenya and South Africa. The paper makes a cost-benefit analysis of these and other tax amnesties - and from this analysis develops a model tax amnesty, whose features maximise the benefits of a tax amnesty while minimising the potential costs. The model tax amnesty: (1) is permanent, (2) is available only to taxpayers who make a voluntary disclosure, (3) relieves taxpayers of penalties, interest and the risk of prosecution, but treats intentional and unintentional non-compliance differently, (4) has clear reporting requirements for taxpayers, and (5) is communicated clearly to attract non-compliant taxpayers without appearing unfair to the compliant ones.

The paper then focuses on the Ugandan tax amnesty introduced in July 2019 - a Voluntary Disclosure Programme (VDP). As at 7 November 2020, this initiative had raised USh16.8 billion (US\$6.2 million) against a projection of USh45 billion (US\$16.6 million). The paper examines the legal regime and administration of this VDP, scoring it against the model tax amnesty. It notes that, while the Ugandan VDP partially matches up to the model tax amnesty, because it is permanent, restricted to taxpayers who make voluntary disclosure and relieves penalties and interest only, it still falls short due to a number of limitations. These include: (1) communication of the administration of the VDP through a public notice, instead of a practice note that is binding on the tax authority; (2) uncertainty regarding situations where a VDP application is made while the tax authority has been doing a secret investigation into the taxpayer's affairs; (3) the absence of differentiated treatment between taxpayers involved in intentional non-compliance, and those whose non-compliance may be unintentional; (4) lack of clarity on how the VDP protects the taxpayer when non-compliance involves the breach of other non-tax statutes, such as those governing financial regulation; (5) absence of clear timelines in the administration of the VDP, which creates uncertainty; (6) failure to cater for voluntary disclosures with minor errors; (7) lack of clarity on VDP applications that result in a refund position for the applicant; and (8) lack of clarity on how often a VDP application can be made. The paper offers recommendations on how the Ugandan VDP can be aligned to match the model tax amnesty, in order to gain the most from this compliance tool.

Keywords: tax amnesty; voluntary disclosure programme; Uganda; Africa; tax administration; Uganda Revenue Authority. 
Solomon Rukundo is an officer in the Business Policy Division of the Domestic Taxes Department of Uganda Revenue Authority, and a research associate at the Mawazo Tax Policy Research Centre in Kampala. 


\section{Contents}

Summary 3

Acknowledgements $\quad 6$

Acronyms 6

Exchange rates $\quad 6$

$\begin{array}{ll}\text { Introduction } & 7\end{array}$

$1 \quad$ Taxpayer non-compliance $\quad 7$

$2 \quad$ Tax amnesties generally 9

2.1 Temporary tax amnesties 10

2.2 Permanent tax amnesty (VDP) 10

2.3 Tax amnesties around the world 11

2.3.1 United States $\quad 11$

2.3.2 Australia 12

2.3.3 Canada 13

2.4 Tax amnesties in Africa 14

2.4.1 Kenya $\quad 15$

2.4.2 South Africa $\quad 15$

2.5 A cost-benefit analysis of tax amnesties 17

2.5.1 Benefits from tax amnesties $\quad 17$

2.5.2 Costs of tax amnesties 18

$3 \quad$ A model tax amnesty 21

$4 \quad$ Tax amnesties in Uganda 21

4.1 The current Voluntary Disclosure Programme in Uganda 22

4.1.1 Discretion under section 66(1a) of the TPCA 22

4.1.2 Requirements of a valid voluntary disclosure under
section 66(1a)

4.1.3 Procedure of applying for the VDP 28

$5 \quad$ Strengths of the Ugandan VDP 29

$6 \quad$ Limitations of the Ugandan VDP and recommendations 30

6.1 Use of public notices instead of practice notes 30

$\begin{array}{lll}6.2 & \text { Secret investigations } & 30\end{array}$

6.3 VDP does not cater for different forms of non-compliance 31

6.4 VDP's interaction with other laws remains unclear 32

6.5 Absence of timelines 32

6.6 Allowance for minor errors 33

6.7 VDP applications that result in a refund position 33

6.8 Repeated VDP applications 33

$\begin{array}{lll}7 & \text { Conclusion } & 34\end{array}$

$8 \quad$ References $\quad 35$ 


\section{Acknowledgements}

The author is grateful for support and encouragement received from colleagues in the Business Policy Division of the Domestic Taxes Department at the Uganda Revenue Authority. The author is also grateful for helpful comments from Mr Philip Karugaba of ENS Africa, who reviewed an initial draft of this paper. Finally the author is grateful for the comments received from ICTD reviewers. Any remaining errors are the author's own.

Comments about this paper can be sent to srukundo@ura.go.ug or soloruk12@gmail.com.

\section{Acronyms}

$\begin{array}{ll}\text { ATO } & \text { Australian Taxation Office } \\ \text { CRA } & \text { Canada Revenue Agency } \\ \text { DTS } & \text { Digital Tax Stamps } \\ \text { EFRIS } & \text { Electronic Fiscal Receipting and Invoicing System } \\ \text { GRA } & \text { Ghana Revenue Authority } \\ \text { GST } & \text { Goods and Services Tax } \\ \text { HNWI } & \text { High Net Worth Individual } \\ \text { IRS } & \text { Internal Revenue Service } \\ \text { OIC } & \text { Offer in Compromise } \\ \text { SARS } & \text { South African Revenue Service } \\ \text { TAA } & \text { Tax Administration Act } \\ \text { TPA } & \text { Tax Procedures Act } \\ \text { TPCA } & \text { Tax Procedures Code Act } \\ \text { UNECA } & \text { United Nations Economic Commission for Africa } \\ \text { URA } & \text { Uganda Revenue Authority } \\ \text { US } & \text { United States } \\ \text { VAT } & \text { Value added tax } \\ \text { VDP } & \text { Voluntary Disclosure Programme }\end{array}$

\section{Exchange rates (2020)}

\author{
Australian Dollar \\ Canadian Dollar \\ Euro \\ Ghanaian Cedi \\ Namibian Dollar \\ South African Rand \\ Uganda Shilling
}

$\begin{array}{ll}\mathrm{A} \$ 1= & \text { US } \$ 0.6843 \\ \text { Can } \$ 1= & \text { US } \$ 0.743065 \\ € 1= & \text { US } \$ 1.134706 \\ \mathrm{GHC} 1= & \text { US } \$ 0.176814 \\ \mathrm{~N} \$ 1= & \text { US } \$ 0.059928 \\ \mathrm{R} 1= & \text { US } \$ 0.060151 \\ \text { USh1 }= & \text { US } \$ 0.000370541\end{array}$




\section{Introduction}

Various forms of national and subnational tax amnesty initiatives have taken place around the world in recent years, in both developing and developed economies. There have been more than 60 amnesty programmes conducted in different states in the United States (US) since 1982 (Luitel 2014). In the developing world, South Africa introduced tax amnesties in 2003 and 2006, and a Voluntary Disclosure Programme (VDP) in 2011 (Dare et al. 2018). The Organisation for Economic Co-operation and Development (OECD) considers tax amnesty programmes to be: 'an integral part of a broader compliance strategy - they need to be considered as part of a variety of compliance actions that tax administrations and governments take in order to encourage all taxpayers to meet their obligation' (OECD 2015: 7).

A 2019 OECD report estimates that since 2009 VDPs in 40 jurisdictions resulted in the collection of an additional $€ 102$ billion in tax revenue, with over 1 million taxpayers disclosing their assets voluntarily (OECD 2019). Amidst the Covid-19 pandemic, tax amnesties have been one important way of providing relief to taxpayers around the world (Reyes-Tagle and Ospina 2020).

In July 2019, Uganda introduced a tax amnesty programme in the form of a VDP. As at 7 November 2020, this initiative had raised approximately USh16.8 billion (US $\$ 6.2$ million) against a target of USh45 billion (US\$16.6 million). This paper examines the legal regime and application of the Ugandan VDP. It begins with examining tax non-compliance, explaining why taxation is a suitable candidate for amnesty in Uganda. It looks at the use of tax amnesties in other jurisdictions, provides a cost-benefit analysis of these amnesties, and develops a model tax amnesty from this analysis. The paper then analyses how the current VDP in Uganda operates, and scores it against the model tax amnesty. The paper highlights the Ugandan VDP's limitations, concluding with recommendations on how it can be improved.

This paper relies on primary sources, including domestic and foreign tax statutes, case law from Uganda and other jurisdictions, public notices and circulars; and secondary literature, including academic articles and tax authority reports - which help understand the general rationale for tax amnesties, and the experience of other jurisdictions administering them. Analysis of domestic tax statutes was important to understand the legislative framework for VDP in Uganda. Analysis of foreign tax statutes was useful for comparative assessment of the Ugandan VDP. Case law from Uganda and selected jurisdictions, including Kenya, Canada, India, South Africa and the US, was analysed to understand judicial interpretations of different provisions relating to the VDP and tax amnesties. Canadian case law was particularly helpful, because documents accessed at the Uganda Revenue Authority showed that the administration of Uganda's VDP was modelled on that of Canada.

\section{Taxpayer non-compliance}

Tax compliance remains a major challenge globally. A 2011 study in the US estimates that 18 per cent to 23 per cent of total reportable income may not be reported to the Internal Revenue Service (IRS), giving rise to a tax gap ${ }^{1}$ in the range of US $\$ 390$ to US $\$ 537$ billion

The tax gap is the difference between total taxes owed or those that would be collected under full compliance, and actual taxes collected. 
(Feige and Cebula 2011). In 2019 the IRS released tax gap estimates for tax years 2011, 2012 and 2013 that show that only 83.6 per cent of taxes were paid voluntarily and on time (IRS 2019). The EU tax gap resulting from largely domestic tax evasion is estimated to be $€ 825$ billion a year (Murphy 2019). The United Nations Economic Commission for Africa (UNECA 2019) estimates the value added tax (VAT) tax gap in 24 African countries including Uganda, and finds that 12 countries have VAT gaps greater than 50 per cent. The Central African Republic has the highest VAT gap at 92.2 per cent, Uganda comes third at 71.4 per cent, while South Africa has the lowest VAT gap at 13.3 per cent (UNECA 2019). This is in line with a 2018 study that found that only 30 per cent of potential VAT revenue is collected in Uganda (Lakuma and Sserunjogi 2018). A 2019 study of income tax evasion in Uganda estimates the income tax gap to be 49 per cent (Lakuma 2019).

There are many forms of tax non-compliance in Uganda, including:

- Non-compliance by elite high net worth individuals (HNWIs), who invest in foreign tax havens and benefit from political capital and connections in evading taxes (Kangave et al. 2016). The 2017 Paradise Papers reveal how a prominent Ugandan politician had significant offshore investments in a tax haven (AlJazeera 2017).

- Aggressive tax planning by multinational corporations, who take advantage of international tax norms and the difficulty of accessing financial information from other jurisdictions, to engage in illicit financial flows and pay the least amount of tax possible (Global Financial Integrity 2018). The 2016 Panama Papers leak reveal how a multinational oil corporation had avoided taxes in Uganda using double taxation agreements (BBC 2016).

- Relatively large local corporations that take advantage of the tax administration body's limited audit capacity and access to information to under-declare their sales and income (Almunia et al. 2015).

- Professionals, such as lawyers, doctors, architects, surveyors, with significant earnings, some of whom may be categorised as HNWIs (UBOS 2018; Kangave et al. 2016). A 2019 study of income tax evasion in Uganda estimates that 62 per cent of professionals are involved in evasion and avoidance (Lakuma 2019). It has been reported that many professionals invest their untaxed earnings in land and commercial buildings (Kangave et al. 2016).

Tax non-compliance also takes place when individuals in the informal sector underreport their income. The informal sector in Uganda is estimated to account for 52.4 per cent of GDP in Uganda, and yet contributes little in taxes (Akol 2015). In FY2019/2020 the informal sector contributed only USh5.2 billion in direct taxes, out of USh16.7 trillion collected (URA 2020a: 9). Generally the informal sector is non-compliant because it remains hidden, untouched by existing business regulations (Mawejje 2013; Joshi et al. 2014). Most businesses in the informal sector do not register for taxes. The taxpayer register in Uganda had only 1.6 million voluntarily registered taxpayers, out of an estimated working population of 15.1 million in June 2020 (UBOS 2018b: 48; URA 2020a: 36). The informal sector includes smallholder farmers, who live just above subsistence level and sell surplus produce, and small retail businesses, including market stalls and kiosks, small restaurants, charcoal burners, transport service providers, and brewers of local drinks (UBOS 2018a: 134). Other economic activities, such as leasing of residential and commercial premises, are also run in a very informal manner (Gardner et al. 2020).

Although the individual amount owed by each business in the informal sector may be small, due to the low income of most operators and correspondingly low tax rates, collectively the tax debt owed is potentially substantial. From the state's perspective, the cost of auditing each business would be high relative to tax revenue, owing to the large number of individual 
firms and difficulty of monitoring them (Joshi et al. 2014). The informal sector thus enjoys low risk of audit and penalisation, which, together with high cost of detection and enforcement relative to tax revenue, provide poor incentive for voluntary compliance (Joshi et al. 2014).

Tax non-compliance also thrives due to low tax morale - the attitude towards paying taxes, including how compliant taxpayers view potential tax non-compliance of their fellow citizens (Barone and Mocetti 2009). Many Ugandans believe that taxes are too high, the tax system is unfair and public services are poor, resulting in low tax morale (Ali et al. 2014). Tax evasion is therefore partly accepted as a minor disobedience, rather than as undermining the functioning of the state in general. It is generally accepted as a kind of popular gaming activity, in which the state sometimes wins and sometimes loses (Ali et al. 2014).

Amnesties are usually granted for offenses committed by a relatively large number of otherwise law-abiding ordinary citizens. A frequently flouted law ordinarily becomes illegitimate, and is soon modified. However, in certain cases changing the law is particularly undesirable, and some form of amnesty may provide a way to recapture legitimacy (Leonard and Zeckhauser 1987). Amnesties are more likely to be applied:

- to offences that do not directly damage an identified party

- to victimless offences against the state

- where it is difficult to enforce the penalty, such as where the offence is committed by a large group of people and the cost of enforcement may outweigh any gains that could be derived from such actions (Leonard and Zeckhauser 1987).

The discussion in this section shows that:

- non-compliance with tax laws is a phenomenon present in all segments of society. Highlevel criminal tax evasion does occur, but ordinary citizens who are usually law-abiding also participate in tax non-compliance

- non-compliance is a result of a variety of factors, including a perception of tax rates being too high and the tax system being unfair

- the tax authority has limited resources to conduct audits, investigations and enforcement. ${ }^{2}$ Tax non-compliance is therefore a suitable potential candidate for amnesty.

\section{Tax amnesties generally}

A tax amnesty is an opportunity given to taxpayers to write off an existing tax liability, including in certain cases interest and penalties, usually by paying a defined amount (Marchese 2019). A tax amnesty may be exceptional and available for only a limited period of time, or it may be inbuilt as a permanent feature of a tax regime where a taxpayer fulfills certain conditions. Tax amnesties may be general - covering all taxes and all taxpayers - or restricted to certain groups of taxpayers or taxes, and usually involve waiving criminal and civil penalties (Marchese 2019). Given the global nature of tax compliance challenges, tax amnesties in one form or another have been used by virtually all revenue authorities around the world. Some tax amnesties have been applied in a formal manner through amendment of the tax law, creating a temporary or permanent application process and documentation that is advertised by the tax authority. Others are not advertised - most revenue authorities waive or do not apply some penalties for taxpayers who ascribe their non-compliance to

e.g. in FY2018/2019 only 142 (27\%) of 527 scheduled audits for domestic taxes were completed (URA 2019). 
administrative error, or who voluntarily declare and pay tax and interest on previously undeclared income (Leonard and Zeckhauser 1987).

Under a tax amnesty, the tax authority may not collect payments through standard means, such as audits, injunctions or litigation in courts. Tax amnesties are therefore usually limited to taxpayers not yet under audit or investigation - where the collectible revenue has not yet been ascertained by the tax authority. However, tax amnesties sometimes include situtaions where the ordinary collection process has already commenced, and where the taxpayer has already been assessed. In these instances the ensuing opportunity cost may be considerably larger (Marchese 2019). Tax amnesties are usually supported by other interventions that range from reform of the tax system, to specific provisions aimed at strengthening tax enforcement powers. The underlying rationale is to accompany the carrot of amnesty with the stick of strict enforcement, in order to mitigate any negative effects on compliance. These interventions often include harsher penalties for non-compliance, increasing the capacity of tax auditors and investigators, modification of laws regulating tax shelters, and sometimes directing a portion of funds collected through the amnesty towards financing increased enforcement activities (Marchese 2019).

\subsection{Temporary tax amnesties}

Temporary amnesties are usually aimed at specific taxpayers for a defined period in order to deal with a specific issue. They are available to taxpayers who meet specific criteria and come forward within a specified timeframe to declare their non-compliance. The OECD notes that temporary amnesties are more targeted than permanent ones (OECD 2015). Temporary amnesties are usually justified by the claim that non-compliance with the tax law may be due to special circumstances, such as large scale tax reform, or major upheavals, such as political regime change or changes in currency. However, temporary tax amnesties tend to be used more frequently than exceptional circumstances alone would warrant. The first temporary amnesty is usually called a 'final amnesty', although others often eventually follow (Marchese 2019).

\subsection{Permanent tax amnesty (VDP)}

A permanent amnesty usually takes the form of a VDP run by the tax authority, where any taxpayer can at any time declare their non-compliance, and, subject to certain conditions, benefit from a waiver of interest or penalties, or both. Given the nature of the tax enforcement problem that necessitates amnesties in the first place, a quick change in taxpayer behaviour is likely to be difficult to achieve. Consequently, temporary amnesties are likely to experience credibility problems, and may result in inefficiency. The public's beliefs will likely be slow to change, and little revenue may result from a temporary amnesty (Stella 1991). This is especially so in developing countries, where the population has little trust in the tax authority (Ali et al. 2014). A long-term, or permanent, tax amnesty via a VDP may be preferable.

A permanent tax amnesty helps the most unfortunate to improve their circumstances, while easing their return to legal compliant behaviour. Over time, economic shocks may affect certain firms or individuals disproportionately (e.g. sectorial crises and adverse life events). Non-compliance with tax laws may be used as a method of increasing disposable income in such circumstances. As there will always be some individuals experiencing these economic challenges, a standing permanent tax amnesty like a VDP is justified in terms of efficiency as a kind of social insurance, and maintaining equity by providing a lifeline for those most in need (Marchese 2019). 
The OECD has developed a decision tree listing six factors that tax administrations ought to consider when designing and administering a VDP:

1. Reason for the VDP, and whether it will be temporary or permanent.

2. Scope of the VDP, including whether it will be available to all taxpayers or only those who meet specific criteria.

3. Terms of the VDP, such as determining the incentive for a taxpayer to come forward.

4. Reporting requirements for taxpayers.

5. Opportunity for intelligence gathering through the VDP.

6. Communication strategy - to attract target non-compliant taxpayers, and avoid creating perceptions of unfairness among compliant taxpayers (OECD 2015).

\subsection{Tax amnesties around the world}

One of the earliest known tax amnesties was inscribed on the Rosetta Stone in Egypt in 200 BCE, during the reign of Ptolemy V. In For Good and Evil: The Impact of Taxes on the Course of Civilization, Charles Adams notes that:

At the time the Rosetta Stone was inscribed, Egypt had been plagued by a civil war for over a decade. This war started after Egyptian soldiers returned home from a successful military campaign in the east; they found Egypt shackled with new tax burdens. In addition, the tax bureau had been strengthened with tough Greeks who were the best in the business. The revolt of these soldiers turned into a civil war, and to try to restore order the boy-king, Ptolemy V, issued a 'Proclamation of Peace'. The most important provision was a general amnesty for the rebels. Tax debtors and rebels were freed from prison. Tax debts were forgiven. There would be no more forced conscriptions for the navy. Fugitives were invited to return and take back confiscated property. Finally, there would be tax immunity for the temples and their crops and vineyards, as in the days of the pharaohs (Adams 2001: 19).

In recent years tax amnesties have been offered by many countries around the world. Luitel (2014) examines the temporary time-limited tax amnesties offered by several countries including Venezuela (1996), Panama (1974), Argentina (1987 and 1995), Belgium (1984), Columbia (1987), Costa Rica (1995 and 2003), France (1982 and 1986), India (1981 and 1997), Ireland (1988 and 1993), Italy (1973, 1982, 1991 and 2003) and New Zealand (1988). A few countries have adopted permanent VDPs, and these are examined in detail below.

\subsubsection{United States}

In the US, the VDP has chiefly functioned to create immunity from prosecution. Between 1919 and 1934, the tax authority would consider Offers in Compromise (OICs) in voluntary disclosure cases. An OIC is an agreement between a taxpayer and the tax authority, settling a taxpayer's tax liabilities for less than the full amount owed. However, as the policy was not publicly promoted, its exact application remains unclear (Madison 2001). Between 1934 and 1952, the tax authority instituted a formal policy whereby it would not recommend criminal prosecution for taxpayers who revealed tax offences to a revenue official prior to the commencement of an investigation. This policy was only officially communicated in 1945 by the Secretary of the Treasury (Blackwell 1980). While the policy was in force, courts treated it as providing taxpayers with immunity from prosecution (Madison 2001). However, there were numerous difficulties in the administration of the VDP, due to lack of specific guidelines on what amounted to a voluntary disclosure - resulting in continuous litigation on the issue. The policy was abandoned in January 1952 (Blackwell 1980). The Tax Section of the American Bar Association attempted to have the policy reinstated with greater administrative flexibility, 
but to no avail. In 1960 the Treasury Department communicated that it would not re-institute a VDP, even at an administrative level (Blackwell 1980).

Between 1961 and 1990 an informal VDP was operational, whereby voluntary disclosure of a tax crime was considered in deciding whether or not to prosecute the offender. However, courts held that this informal practice provided defendants with no legally enforceable rights (Madison 2001).

In 1990, the IRS adopted the Internal Revenue Manual section 342.142, which provided for a VDP whereby no prosecution would be recommended. To qualify for the VDP, the disclosure had to be: a) truthful, (b) timely, (c) complete, and (d) showing a willingness to cooperate with the IRS in determining the correct tax liability (Madison 2001). This is the position in the current IRS VDP. A disclosure is timely if it is done before the IRS has commenced a civil examination or criminal investigation, received information from a third party, or acquired information through a criminal enforcement action. The disclosure process has two parts: the taxpayer first submits a pre-clearance form to determine eligibility for the VDP; where eligibility is confirmed the disclosure form is submitted (IRS 2020).

\subsubsection{Australia}

The Australian VDP focuses largely on reduction of penalties applicable for non-compliance. It was introduced by the Taxation Laws Amendment (Self-Assessment) Act 1992 (Australia), which provided that where a taxpayer voluntarily discloses a tax shortfall prior to an audit the penalty is reduced to nil if the shortfall was less than $A \$ 1,000$, and by 80 per cent if the shortfall was A $\$ 1,000$ or more. In January 1994 the Australian Taxation Office (ATO) issued a tax ruling clarifying that: 'certain disclosures may be treated as having been made voluntarily, notwithstanding that they are made after notification of an audit, where the disclosure is about a matter outside the scope of the audit or it could be concluded that the disclosure would have been made even if the audit had not been commenced' (ATO 1994: 3).

The 1994 tax ruling also provides that where the disclosure is incomplete, but the degree of incompleteness is insignificant, the case may still be treated as a voluntary disclosure. However, it also noted that making a voluntary disclosure did not necessarily preclude a prosecution (ATO 1994).

In 2000 the Taxation Administration Act 1953 (Australia) was amended to introduce section 284-225 of Schedule 1. This provided for a reduction in penalty on the same terms as the Taxation Laws Amendment (Self-Assessment) Act 1992, but also introduced a provision that where the taxpayer discloses non-compliance after an audit starts, the reduction is 20 per cent if the disclosure saves the ATO significant time or resources.

A new tax ruling was issued in November 2008, which introduced a new definition of voluntary disclosure as an act of admission done without prompting, persuasion or compulsion on the part of the Commissioner (ATO 2008). It also clarified that for the purposes of section 284-225 a tax audit was not just a traditional audit, but included any examination of an entity's financial affairs (ATO 2008).

This 2008 tax ruling was withdrawn in September 2011 following the enactment of the Tax Laws Amendment (2010 Measures No. 1) Act 2010, which made significant amendments to section 284-225. These included replacing the statutorily defined term 'tax audit' with the wider phrase 'examination ... of your affairs relating to a taxation law', and a reduction of penalty to nil for disclosure of a false or misleading statement that does not result in a 
shortfall. A new tax ruling was subsequently issued in 2012 , defining voluntary disclosure as an act done without persuasion or compulsion on the part of the Commissioner (ATO 2012). The disclosure must be made prior to any direct contact with the entity or the entity's representative by the Commissioner. The ruling notes that a disclosure made after the notification of an examination in relation to one taxation law only is regarded as having been made voluntarily if the disclosure relates to another taxation law. The ruling, however, cautions that it does not deal with whether or not an entity will be prosecuted where they have made a voluntary disclosure. Examination of an entity's affairs is defined as including reviews, audits, verification checks, record-keeping reviews/audits and other similar activities. It is not restricted to calculation of tax-related liabilities, but includes examinations in relation to debt collection, registration, reporting or other matters (ATO 2012).

\subsubsection{Canada}

Canada has had a VDP for many years. Information circulars published in 1970 and 1973 indicate the existence of a VDP whereby taxpayers who made a voluntary disclosure would not be prosecuted or assessed for penalties (OAG 2004; Friedman 2016). The modern VDP emerged in June 2000, when the Canada Revenue Agency (CRA) issued an information circular in respect of the VDP (Friedman 2016). The information circular was based on subsection 220(3.1) of the Income Tax Act (Cananda) and sections 88 and 281.1 of the Excise Tax Act (Cananda), which give the Minister of National Revenue the legislative authority to waive or cancel any interest or penalty (OAG 2004). The circular has been revised and updated a number of times, with minor variations with each revision (Friedman, 2016). The most recent version was issued in 2017 as Information Circular, IC00-1R6 Voluntary Disclosures Program (CRA 2017).

Under Canada's VDP, taxpayers who make a valid voluntary disclosure are not subject to prosecution and are generally relieved of the obligation to pay penalties. Interest relief, however, is only partial. The Minister may grant partial interest relief in respect of reporting periods preceding the three most recent years of returns required to be filed as a result of the disclosure (CRA 2017). With few exceptions, taxpayers are entitled to rely on the VDP once, and are thereafter expected to remain compliant. A subsequent application for relief under the VDP may only be considered if it is due to circumstances beyond the taxpayer's control, and related to a different matter than the first application (CRA 2017).

In addition to the information circular, CRA has a detailed VDP manual that guides staff in the administration of the programme. Although it has not been officially released, redacted copies of the VDP manual have been accessed by tax agents through access to information laws. The manual sets out in detail the criteria to be applied by CRA, the questions to be posed to taxpayers, the documentation and internal protocols to be followed, and the research and other steps to be followed. The CRA also periodically issues special announcements regarding circumstances under which the VDP will not be applied. For example, when the Panama Papers leaked in 2016, the CRA issued a communication that taxpayers named therein could not benefit from VDP (Friedman 2016).

To qualify for VDP, the disclosure must be voluntary, complete, involve the application of a penalty, include information that is at least one year past due, and include payment of the estimated tax owing (CRA 2017). To be voluntary, the taxpayer must have lacked knowledge or awareness of any enforcement action. For purposes of the VDP, an enforcement action includes but is not limited to an audit, examination, investigation, requests, demands or requirements issued by the CRA, or direct contact by a CRA employee for any reason relating to non-compliance (CRA 2017). Computer-generated notices are prima facie an enforcement action; however where the CRA has not followed up on a computer-generated 
notice that was issued far in the past, it may not be considered as such (Friedman 2016). To be complete the disclosure must be made for all relevant taxation years where there was previously inaccurate, incomplete or unreported information. Taxpayers are expected to submit all relevant information or documentation with their VDP application. In extraordinary circumstances, the taxpayer may request an additional period of time (generally not exceeding 90 days) to submit additional information to complete the application. Where books and records no longer exist, the taxpayer should make all reasonable efforts to estimate the income for those years (CRA 2017).

Initially, the CRA required all taxpayers making disclosures to identify themselves clearly in their VDP applications. However, the no-name disclosure process was introduced in 2007, allowing anonymous disclosures (CRA 2007). The taxpayer's advisor would communicate with the CRA, revealing the circumstances but not the name of the taxpayer. The identity would only be revealed if the CRA provided some indication that the taxpayer would qualify for the VDP (Friedman 2016). In most cases, the CRA stated that the taxpayer in question was not precluded from making a disclosure.

Following a 2016 report by the Offshore Compliance Advisory Committee, a number of changes were introduced to the VDP (OCAC 2016). The no-name disclosure method was replaced by a pre-disclosure discussion service, whereby taxpayers or their authorised representatives may have a non-committal conversation with a CRA official on an anonymous basis. The VDP was split into two programmes: the limited programme and the general programme. The limited programme provides limited relief for VDP applications where the facts indicate an element of intentional non-compliance. Factors such as efforts made to avoid detection, the amounts involved (VDP applications by corporations with gross revenue in excess of Can $\$ 250$ million are generally considered under the limited programme), the number of years of non-compliance and the sophistication of the taxpayer. Under the limited programme, the taxpayers escape prosecution and are not charged a gross negligence penalty. However, they are charged other penalties and interest as applicable. In other cases, the general programme would normally apply. Under the general programme taxpayers are not charged penalties, are not referred for criminal prosecution, and benefit from partial interest relief.

\subsection{Tax amnesties in Africa}

Several tax amnesties have been offered by African countries in recent years. In December 2016 the Namibian Cabinet of Ministers initiated a tax amnesty programme lasting up to 31 July 2017, writing off 70 per cent of interest and waiving all penalties (Namibia Economist 2017; EY 2018).

The Government of Ghana passed the Tax Amnesty Act 2017, (Act 955), which took effect in January 2018, granting amnesty to unregistered persons and registered persons who failed to file their tax returns or pay taxes. A person seeking to benefit from the amnesty was required to register with the GRA and file income tax returns for FY2014 to FY2016 by 30 September $2018 .^{3}$

In Tanzania, the Tax Administration (Remission of Interest and Penalty) Order, 2018 was issued under the Tax Administration Act, 2015, giving power to the finance minister to issue regulations governing the Commissioner's power to waive all or part of interest and penalties. The Order came into force on 1 July 2018 and expired on 31 December 2018. Eligible taxpayers enjoyed a 100 per cent waiver of interest and penalties, but had to pay the

Section 1 of the Tax Amnesty Act 2017, (Act 955). 
outstanding principal amount of tax not later than 30 June 2019. Unregistered persons, nonfilers, persons with pending tax disputes and ongoing audits were also allowed to apply.

In Nigeria, the president issued Executive Order No. 004 in June 2017 to create a tax amnesty that ran from 1 July 2017 to 31 March 2018, offering taxpayers immunity from prosecution, waiver of interest and penalties, and an option to make instalment payments of the principal amount of the unpaid tax over three years. ${ }^{4}$ It extended to taxpayers undergoing tax audit or investigation, or who were in dispute with the tax authorities in tribunals or courts.

At least two countries in Africa have developed a permanent or semi-permanent VDP. South Africa has a permanent VDP, while Kenya will start a three-year VDP on 1 January 2021.

\subsubsection{Kenya}

The Finance Act 2020, which came in force in June 2020, amends the 2015 Tax Procedures Act by introducing section 37D, which creates a three-year VDP that commences on 1 January $2021 .{ }^{5}$ Relief from prosecution, penalties and interest is granted to a person who discloses their tax liabilities to the Commissioner. ${ }^{6}$ The tax liabilities must have accrued within a period of five years prior to 1 July $2020 .{ }^{7}$ The penalty waiver and interest will be granted to taxpayers at a rate of 100 per cent for disclosures made within the first year, 50 per cent for disclosures in the second year and 25 per cent for disclosures in the third year of the programme. ${ }^{8}$ The Act provides that the disclosure 'shall be voluntary and disclose all material facts'. ${ }^{9}$ The VDP therefore does not apply where the taxpayer is 'under audit, investigation or is a party to ongoing litigation in respect of the tax liability or any matter relating to the tax liability; or has been notified of a pending audit or investigation by the Commissioner'. ${ }^{10}$ Where the Commissioner discovers that a taxpayer benefiting from VDP failed to disclose a material fact in respect of the relief, the Commissioner may withdraw any relief granted, or assess and collect any balance of the tax liability, or commence prosecution. ${ }^{11}$

\subsubsection{South Africa}

South Africa has instituted a number of tax amnesties over the years. In 1995, the government allowed unregistered persons a window from 10 July to 31 January 1996 in which they could be fully registered as taxpayers without payment of any penalty (Dare et al. 2018). A second amnesty was introduced in 1996 through the Final Relief on Tax, Interest, Penalty and Additional Tax Act. ${ }^{12}$ This applied to unregistered persons and registered nonfilers, as well as taxpayers who filed with errors in their tax returns. ${ }^{13}$ The Act provided relief from the requirement to pay the principal amount of tax for any year of assessment that ended on or before 28 February 1994, as well as relief from penalty, interest and prosecution. ${ }^{14}$ The taxpayer benefiting from the VDP only had to pay the principal tax due in

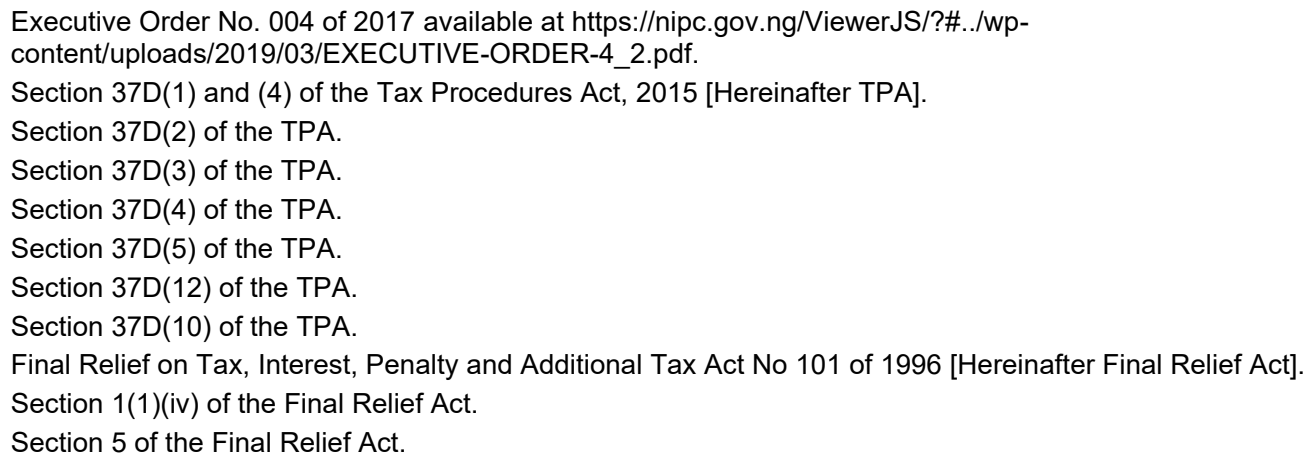


respect of the last two years of assessment that ended before 1 March 1996. The Act provided for a relief period lasting from 1 November 1996 to 28 February $1997 .{ }^{15}$

In 2003, the South African government introduced the Exchange Control Amnesty and Amendment of Taxation Laws Act of 2003. ${ }^{16}$ This law provided amnesty from 1 June to 30 November 2003 for taxpayers with undisclosed offshore income to correct their affairs. The law provided that a taxpayer benefiting from the amnesty would not be liable for tax in respect of any undeclared income from a source outside South Africa during any year of assessment ending on or before 28 February 2003, and would be deemed not to have committed any offence. ${ }^{17}$ The taxpayer, however, had to pay a domestic tax amnesty levy of 2 per cent of the declared amount.

In 2006, the South African government introduced the Small Business Tax Amnesty and Amendment of Taxation Laws Act, which provided an amnesty from 1 August 2006 to 31 May 2007 to small businesses - businesses whose gross receipts did not exceed R10 million (USD 600,000) - which voluntarily declared their unreported income and complied with the tax legislation. ${ }^{18}$ The law also provided for a progressive tax amnesty levy from 0 per cent to 5 per cent of the taxable income. ${ }^{19}$ The Small Business Tax Amnesty was introduced to deal with the taxi industry, which, due to its informal nature, remained outside the tax base despite being valued as a multi-billion rand industry (Junpath et al. 2016).

In 2012, the Tax Administration Act 28 of 2011 was passed. Sections 225-233 of this law provide for the current permanent South African VDP. The VDP applies to all taxes administered by South African Revenue Service (SARS), with the exception of customs and excise. Any person can voluntarily disclose their non-compliance unless they are aware of a pending audit or investigation, or an audit or investigation has already commenced. ${ }^{20}$ However, even with an ongoing audit or investigation, a senior SARS official may direct that the taxpayer apply for the VDP where the default disclosed would not otherwise have been detected during the audit or investigation, and the application would be in the interest of good management of the tax system and best use of SARS' resources. ${ }^{21}$

Similar to the Canadian VDP, to qualify for the South African VDP the disclosure must be voluntary, full and complete in all material respects, involve a previously undisclosed default, not result in a refund due by SARS and be made in the prescribed form and manner. ${ }^{22}$ The VDP allows no-name voluntary disclosure, whereby a tax representative may provide sufficient information without including the identity of the taxpayer, and a senior SARS official may issue a non-binding private opinion in respect of a person's eligibility for relief. ${ }^{23}$

Taxpayers who voluntarily disclose their non-compliance have their understatement penalties reduced and their administrative non-compliance penalties completely waived. ${ }^{24}$ The magnitude of the relief is dependent on whether the disclosure is undertaken prior to or after

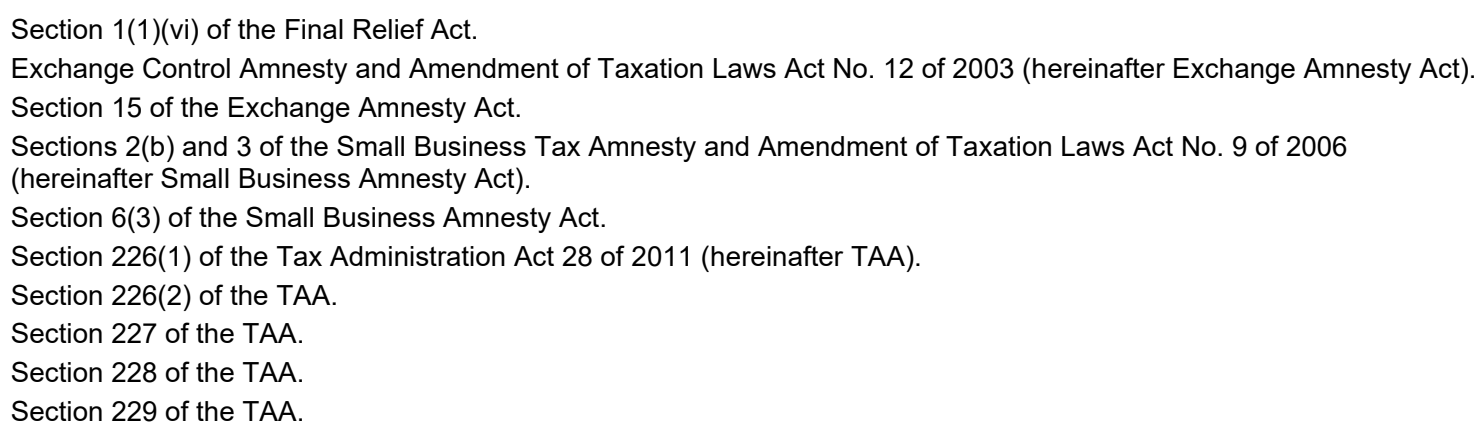


the issuance of an audit notice by the tax authority. ${ }^{25}$ The taxpayer also gets effective immunity from prosecution in respect of any tax offence arising from the default disclosed. ${ }^{26}$

Where a VDP application is accepted, a senior SARS official and the taxpayer sign a written agreement ${ }^{27}$ The Commissioner is required to provide an annual summary of all voluntary disclosure agreements to the Auditor-General and Minister of Finance. The summary must contain details of the number of voluntary disclosure agreements and the amount of tax assessed, but must not disclose the identity of the taxpayer. ${ }^{28}$

\subsection{A cost-benefit analysis of tax amnesties}

\subsubsection{Benefits from tax amnesties}

Tax amnesties provide several benefits to the tax authority, taxpayer, government and society as a whole.

Boost in revenue collection. A critical benefit of a tax amnesty/VDP is that it may lead to a boost in revenue collection. A tax amnesty offers non-compliant taxpayers a chance to wipe the slate clean by paying some or all of what they owe. Research has shown that individuals consider fiscal incentives in deciding whether and to what extent they will participate in an amnesty (Alm and Beck 1991). Allowing known non-compliant taxpayers to participate, such as those already under audit or investigation, may have a positive impact on amnesty revenue. For these taxpayers, the amnesty can be considered a relatively inexpensive means by which a significant portion of their known tax liabilities can be collected (Alm and Beck 1991).

Access to data and intelligence on tax evasion. Tax amnesties may help the tax authority to collect data on tax evasion and other forms of non-compliance. This data can subsequently be used when profiling taxpayers for risk. Basic data that reveals some common characteristics among taxpayers who engage in evasion can be invaluable. While amnesty participants may not necessarily be representative of all evaders, the near total absence of data on non-filers in most tax authorities makes comparison of the characteristics of amnesty participants relative to the taxpaying population useful for tax authorities looking to improve the allocation of their enforcement resources (Fisher et al. 1989).

The tax amnesty can also be used to collect intelligence relating to tax evasion. Given the criminal nature of evasion, collecting information on this is usually very difficult. Some tax authorities require disclosure of certain information, such as documents and information on foreign accounts, assets, institutions and facilitators, for a VDP application to be considered complete. For example, the Italian VDP requires applicants to disclose all participants and facilitators engaged in any tax fraud (Grilli 2015). This is information that can assist the tax authority in identifying tax evasion schemes and those who facilitate them, the methodologies used by tax evaders, and to determine what information and records are likely to be available to an investigator. The tax authority may be able to use this information to identify other non-compliant taxpayers who have not taken part in the VDP. However, considerable tact is needed when determining the scope of intelligence gathering to avoid deterring taxpayers from coming forward in the first place (OECD 2015).

Section 223 of the TAA.

Section 229 of the TAA

Section 230 of the TAA.

Section 233 of the TAA 
Encourage renewed tax compliance. Studies have found that tax amnesties tend to have a positive effect on tax compliance, and many previously non-compliant taxpayers continue to be compliant long after the amnesty has ended (Yucedogru and Sarisoy 2020). In order to continue to hide their past non-compliance, non-compliant taxpayers are often forced to continue to file inaccurate tax returns. A tax amnesty 'makes future adherence to the tax code more likely by removing the need to conceal past sins' (Leonard and Zeckhauser 1987: 61). An analysis of the long-term compliance impact of a three-month tax amnesty in Malawi that ran from 1 November 2013 to 31 January 2014 found that 75 per cent of those who disclosed their non-compliance subsequently remained compliant (Masiya 2019). A study of a tax amnesty in the state of Michigan found that two-thirds of new filers that came forward under the amnesty remained compliant, while 90 per cent of the pre-existing filers who participated in the amnesty remained compliant (Christian and Gupta 2002).

Allow the taxpayer to get rid of guilt. Guilt is a powerful moral emotion that is known to influence ethical decision-making. Tax amnesties encourage non-compliant taxpayers to selfcorrect. A study relying on 239 responses by Canadian taxpayers found that appealing to taxpayers' guilt, through efforts to increase the foreseeability of possible negative consequences of tax evasion, may be a promising strategy in encouraging non-compliers to self-correct (Farrar and Hausserman 2016). The study found that the likelihood of a taxpayer making a disclosure is greatest when the individual assumes personal responsibility for the non-compliance, and can foresee the negative consequences. The study concludes that an emotional appeal for taxpayers to be compliant and pay taxes that should have been remitted may increase tax revenue (Farrar and Hausserman 2016).

Support transition to new enforcement regimes. Where a new enforcement regime is being introduced, tax amnesties can be used to support this enforcement. Tax amnesties can improve the tax authority's operating capacity - they result in the elimination of problematic taxpayer files that need attention, allowing them to reallocate their resources elsewhere (Yucedogru and Sarisoy 2020). Further, where tax laws have not been strictly enforced for a long period of time, and a significant portion of the population has been able to get away with non-compliance, it creates an implicit assumption that non-compliance is not a serious offence (Leonard and Zeckhauser 1987). Where the tax authority is introducing a regime of enhanced collection and detection procedures, harsher penalties, and so on, an amnesty period can be used to ease transition to the new regime. The intervening amnesty period may make the change in regime appear fair. The guilt felt by many would-be-compliant taxpayers can be relieved without imposing severe penalties; harsher penalties can subsequently be used to deal with those tax evaders who choose not to participate (Fisher et al. 1989).

\subsubsection{Cost of tax amnesties}

Tax amnesties may be perceived as unfair to compliant taxpayers. Compliant taxpayers may feel unjustly treated, either because non-compliant taxpayers are not punished, or because they feel foolish for having been compliant (Leonard and Zeckhauser 1987). This is usually the case where the majority have been compliant, and only a minority have been non-compliant. The compliant taxpayers' attitude towards an amnesty has to be taken into account when determining how it will be applied. Compliant taxpayers may feel that an amnesty is a violation of equity, because it results in discriminatory treatment of citizens amnesty participants pay a different amount to compliant taxpayers, and those who were caught before the amnesty. A study of voter reaction to granting of tax amnesties where the majority of the population is compliant showed that governments that granted amnesties shortly before an election were often voted out of power (Torgler and Schaltegger 2005). Tax-compliant taxpayers/voters consider a tax amnesty to be unfair to them, and electorally 
punish governments that offer them. One study of US Governors who lost re-election bids found that they were more than twice as likely to have offered a tax amnesty during their election years (Borgne 2006). A study of taxpayer reaction to the 2016 Turkish tax amnesty found that taxpayer perception of fairness was negatively affected by tax amnesties (Yucedogru and Sarisoy 2020).

In practice, however, tax amnesties may not necessarily be inequitable. Even without amnesties, compliant taxpayers already pay significantly more tax than tax evaders. The tax amnesty collects a little more revenue from tax evaders, thereby reducing the difference between what is paid by the two groups - thereby supporting horizontal equity. Even vertical equity increases where HNWls who evade more take advantage of tax amnesties (Borgne 2006).

Compliant risk becoming non-compliant. Depending on the perceived likelihood of its repetition, a tax amnesty might lead non-compliant taxpayers who hope to benefit from a subsequent amnesty to remain non-compliant, or even incentivise evasion among hitherto compliant taxpayers who anticipate a future tax amnesty (Leonard and Zeckhauser 1987). A study of amnesties issued by states in the US found that the first time a state offers an amnesty results in a short-term revenue boost during the amnesty period, but leads to a reduction in revenue in the long term (Luitel 2014). A study of the 2014 and 2018 tax amnesties in Zimbabwe found that 'a negative association exists between tax amnesties and tax compliance', noting that there was a decline in compliance following each amnesty (Wadesango et al. 2020). This is explained by people responding to the amnesty by beginning to evade taxes, in anticipation of future amnesties. Another explanation is that tax amnesties negatively affect taxpayers' perception of the possibility of being caught by tax authorities. The efficiency of tax inspection deteriorates in an environment where there are frequent tax amnesties. Tax amnesties reduce the fear of being caught by the tax authorities (Yucedogru and Sarisoy 2020). Repeated amnesties also encourage taxpayers to engage in temporary non-compliance, treating the state as a short-term loan provider. Hypothetically, a firm in need of a short-term loan may not remit its monthly tax payments in anticipation of an amnesty, and use that money in lieu of a loan - then pay the tax during the amnesty period (Ross and Buckwalter 2013).

Revenue gains are minimal and often overstated. Despite their apparent popularity, revenue gains from tax amnesties generally appear to be minimal and are often below their target. A 2008 International Monetary Fund study of tax amnesties in the US, Ireland, Italy, Argentina, Turkey and The Phillipines noted that 'amnesties yield additional revenue, although often not as much as expected' (Baer and Borgne 2008: vii). The 2016 Namibian tax amnesty only raised $\mathrm{N} \$ 1.4$ billion (US $\$ 84$ million) against a target of $\mathrm{N} \$ 4$ billion (US $\$ 240$ million), despite three extensions of the amnesty up to March 2018 (Chiringa 2018). The 2018 Ghanaian tax amnesty raised only $\mathrm{GHC} 287$ million (US $\$ 49$ million) against a target of GH\$500 million (US\$88 million) (Larnyoh 2019).

It has also been argued that the true revenue yield from tax amnesties is overstated, because it is not always clear that revenue yield is due to an amnesty. Other factors, such as GDP growth and enhanced tax enforcement that usually accompany tax amnesties, may also contribute to revenue growth. A study of taxpayer data in Kenya following the 2004 tax amnesty finds that it did not have a positive effect on tax revenue growth after controlling for other revenue factors like GDP and inflation (Kilonzo 2012).

Tax amnesties accelerate receipt of funds that would have been collected even without the amnesty, while forfeiting collectable penalties. This is especially the case where the amnesty extends to those already under investigation for tax evasion. A study of the Michigan tax 
amnesty found that the long-term addition to revenue coming from new taxpayers was small, and easily offset by negative effects of the amnesty on tax compliance (Fisher et al. 1989). A study of the tax amnesty programme in Argentina found that the increase in short-term revenue was temporary, and resulted in accelerated collection of taxes, but did not increase the amount collected (Villalba 2017).

Tax amnesties may have a negative impact on long-term tax compliance, offsetting the temporary increase in revenue during the amnesty period. Tax amnesties may thus be a 'penny-wise and pound-foolish' policy that potentially impede long-term revenue goals (Luitel 2014). A study of tax amnesties in the US between 1981 and 2011 found that the benefits are only modest and in many cases do not exceed the costs of such programmes (Bayer et al. 2015). A study of the 2014 and 2018 tax amnesties in Zimbabwe finds that compliance levels declined gradually after the amnesties (Wadesango et al. 2020).

Tax amnesties may distort revenue projection figures and future performance measurement. Revenue forecasting is critical in ensuring stability in government tax and expenditure policies. Forecasts are based on certain underlying methodologies and common assumptions. These rely on currently available information and what is assumed at the time in the estimation process (Jenkins et al. 2000). Tax amnesties may distort forecasting, because in the year the amnesty is applied revenue collection may increase significantly. Where revenue forecasting is based on previous collection, the projected figure for the subsequent year in which there is no amnesty may be higher than it would otherwise have been (Leal et al. 2007). As a result of these distortions, the tax authority may fail to meet the higher projection.

Undermine social sanction against tax non-compliance. Tax amnesties may undermine the strength of social sanction against the amnestied behaviour, thereby reducing the guilt felt by non-compliant taxpayers. While eradication of guilt may be a benefit to taxpayers, it is a cost to the tax authority and to society. Many taxpayers may be compliant simply because they believe it is the right thing to do, and would feel guilty if they did not comply (Leonard and Zeckhauser 1987). Amnesties for tax evasion may make non-compliance seem less significant, thereby reducing the guilt of tax evaders. Guilt and shame are highly efficient tools for social control, and societies struggle to instil the values that create a conscience, and feeling guilt and shame for certain acts. Where guilt and shame are eroded, society must rely on considerably more expensive and less efficient methods to identify and punish those who do not obey the law (Leonard and Zeckhauser 1987).

Tax amnesties remain the second best tool. Tax amnesties are primarily used to overcome structural rigidity in countries in which the enforcement systems suffer from major structural problems. This allows the state to capitalise on its own inefficiency, as it is able to delay needed reforms. Tax amnesties therefore remain the second-best tool, and should only be used when reform of the tax system cannot easily be undertaken (Villalba 2017). An analysis of Nigeria's 2017 amnesty recommended that the government focus on building and strengthening institutions that support accountability and perception of good governance in order to encourage long-term voluntary tax compliance (Okoye 2019). A study of the 2012 offshore VDP in the US noted that such measures are inadequate to deal with recalcitrant evaders who will gamble on continuing to be undetected. The proper solution is long-term enforcement initiatives, such as focusing on exchange of information with other jurisdictions (Lederman 2012). Bilateral exchange of information agreements, and multilateral agreements such as the Multilateral Convention on Mutual Administrative Assistance in Tax Matters, which has been signed by 61 jurisdictions, are better solutions to non-compliance than tax amnesties (OECD 2011). These agreements create a sense of urgency among noncompliant taxpayers - that their offshore assets can be traced more easily. 


\section{A model tax amnesty}

From the above analysis of literature relating to tax amnesties, the following are characteristics of an ideal tax amnesty:

(i) The amnesty ought to be a permament VDP rather than a temporary one. A permanent VDP is more credible and has less impact on the efficiency of tax administration. A permanent VDP maintains equity by providing a lifeline for those most in need. The VDP ought to be accompanied by enhanced compliance and enforcement measures.

(ii) The VDP should apply only to taxpayers who voluntarily disclose their previous noncompliance - who are not under audit or investigation. The VDP may only be extended to such taxpayers where it can be shown that the audit or investigation would not have discovered the non-compliance. A taxpayer should only be able to make a single voluntary disclosure. Allowing for repeated voluntary disclosures risks incentivising noncompliance. Anonymous disclosures ought not to be accepted.

(iii) The VDP should offer a waiver of penalties and interest, but not the principal amount owed as tax. The VDP should offer immunity from prosecution for the tax offence. A distinction should be made between taxpayers who engaged in active tax evasion, such as fraudulent acts and forging documents, and those who engaged in minor noncompliance, such as resulting from ignorance. Only prosecution and penalties should be waived for the former, while both penalties and interest could be waived for the latter.

(iv) The VDP should have clear reporting requirements, including details such as the exact nature of non-compliance and reason for non-compliance. Contracts, books of accounts and financial statements may be required to be submitted with the application. Information relating to tax agents who facilitated intentional non-compliance may also be required. The application procedures ought to be simplified as much as possible, and an online application procedure would be preferable.

(v) The VDP should be communicated very clearly, highlighting the benefits of the programme, to target and attract non-compliant taxpayers. What amounts to voluntary disclosure should be clearly communicated to taxpayers. At the same time, the communication should ensure that compliant taxpayers perceive the VDP as fair.

\section{Tax amnesties in Uganda}

Tax amnesties have been a feature of the Ugandan tax system since the 1990s. In 1999, the Finance Act created an amnesty for all arrears of the coffee stabilisation tax, sales tax and commercial transactions levy. ${ }^{29}$ In 2006 , all arrears of import duties, excise duties, VAT and withholding taxes owed by the government were written off. ${ }^{30}$

In 2007, the Finance Act remitted all arrears of licence fees on motor vehicles, trailers and engineering plants and arrears of VAT owed by local governments as at 30 June $2006 .{ }^{31}$ This law also created a temporary amnesty based on a VDP. A taxpayer who voluntarily disclosed their non-compliance and paid the principal amount of tax on or before 31 December 2007 had the interest and penalties otherwise applicable waived. ${ }^{32}$ The law took effect from 1 July 2007. The URA issued a practice note which detailed the manner in which

\footnotetext{
Section 14 of the Finance Act No 2 of 1999.

Section 2 of the Finance Act, 2006.

Section 6 of the Finance Act, 2007.

Section 5 and 6 of the Finance Act, 2007.
} 
the amnesty was being operationalised (URA 2007). The practice note described a voluntary disclosure as: 'a taxpayer coming out at his own initiative and reporting what is wrong with his declarations before the URA finds out through some other means such as audits or from third party sources'.

Nonetheless the practice note also permitted taxpayers with pending audits to benefit from the amnesty. The initiative received great public approval, but collected only USh41 billion against the target of USh223 billion (ADBG 2010; Musitwa 2007).

Subsequently, more tax amnesties have been offered without the requirement of voluntary disclosure. In 2008 the Finance Act waived all arrears of VAT, income tax, excise duty, import duty, penalties and interest due on or before 30 June 2002 and still outstanding by 30 June 2008. ${ }^{33}$ In 2016 the Finance Act waived all tax arrears owed by Savings and Credit Cooperative Societies as at 31 December 2015. ${ }^{34}$ In 2019 all unpaid taxes owed by government as at 30 June 2019 were written off. ${ }^{35} \mathrm{~A}$ form of amnesty also exists in the Tax Procedures Code Act (TPCA), which provides that an additional assessment can only be made within three years of the self-assessment return to which it relates, unless the taxpayer or their agent has commited fraud or gross neglect. ${ }^{36}$

\subsection{The current VDP in Uganda}

In July 2019, section 66(1a) of the TPCA was introduced. This section provides that where a person who has committed an offence under a tax law voluntarily discloses the commission of that offence to the Commissioner at any time prior to commencement of court proceedings, the Commissioner may enter into an agreement with the offender to compound the offence if the offender agrees to pay to the Commissioner the outstanding unpaid tax, and that person shall not be required to pay any interest or fine due.

Under section 66 of the TPCA, the Commissioner can only compound an offence if the offender admits the offence in writing and requests to enter into a compounding agreement. ${ }^{37}$ The compounding agreement is required to specify the name of the offender, offence committed, the written admission, sum of money to be paid, and date for payment. ${ }^{38}$ The agreement is not subject to any appeal and may be enforced in the same manner as a decree of any court for payment of the amount stated, and serves as proof of the conviction of the offender for the offence specified. ${ }^{39}$

\subsubsection{Discretion under section 66(1a) of the TPCA}

The power to compound a tax offence under section 66(1a) of the TPCA is a discretionary power due to three reasons:

i. The use of the word 'may', which implies discretion.

ii. This is a compounding provision, which generally involves discretion.

iii. VDP provisions in other jurisdictions are usually discretionary.

Section 4 of the Finance Act, 2008.

Section 7 of the Finance Act, 2016.

Section 40A of the TPCA, 2014 as amended.

Section 23(2) of the TPCA.

Section 66(2) of the TPCA.

Section 66(3) of the TPCA.

Section 66(3) of the TPCA. 


\section{The use of 'may'}

Section 66(1a) provides that the Commissioner 'may' enter into a compounding agreement. This implies that the provision is discretionary. In his book, Understanding Statutes, Professor Crabbe notes that: 'The word may is an auxiliary verb which is normally used in a legislative sentence to confer a power, a privilege or a right. Its use implies the permissive, the optional or a discretionary power or conduct. As a general rule, may is not a word of command... May, therefore, in its ordinary meaning, gives an enabling, a discretionary power' (Crabbe 1994: 32).

While 'may' is occasionally interpreted as a command, this is only done where the context or subject matter of the provision indicate that it is intended as such. ${ }^{40}$ This is done such that 'justice may not be the slave of grammar' (Crabbe 1994: 32). As Ruth Sullivan explains in her book, Statutory Interpretation: "May" is always permissive, in the sense that it always confers a power. The power is presumed to be discretionary unless something in the context obliges its recipient to exercise it' (Sullivan 2007: 74). However, there is nothing in section 66(1a) to suggest that 'may' should be interpreted as mandatory - therefore it is discretionary.

\section{Discretion under compounding provisions}

Compounding provisions involve an agreement between a public authority responsible for enforcing a particular provision and an offender who has breached that provision. The compounding agreement is in the nature of a contract, and the public authority will have high discretion in deciding whether or not to enter it. ${ }^{41}$ In the Indian case of Vikram $v$ Union of India ${ }^{42}$ involving compounding of a tax offence, the court observed that: 'Compounding of offences cannot be taken as a matter of right. It is for the law and authorities to determine as to what kind of offences should be compounded, if at all, and under what conditions'. ${ }^{43}$

In Kasibo $v$ URA, ${ }^{44}$ the court likened compounding to plea bargaining, stating: 'Compounding an offence in my understanding is a form of settlement of the offence without prosecution that results into a settlement order. It is a form of plea bargain with the offender that results in an admission of the offence in the expectation, no doubt, of a lighter sentence. This is because no prosecution has taken place saving all concerned valuable time and resources'. ${ }^{45}$ The court therefore considered that if the Commissioner considers a taxpayer to be a 'hard-core' offender, the Commissioner may opt not to compound the offence, and instead prosecute the offender to the fullest extent of the law.

The discretionary power to compound offences is prone to abuse. In describing a compounding provision, the court in URA $v$ Remigious ${ }^{46}$ questioned whether such a provision could even pass constitutional muster given the incredible powers it placed in the hands of the Commissioner General. The court stated: 'The Commissioner-General is given awesome power in which he is in effect the investigator, prosecutor and the judge. The Commissioner-General is a judge in his own cause. No appeals are allowed against this decision of the Commissioner-General'. ${ }^{47}$

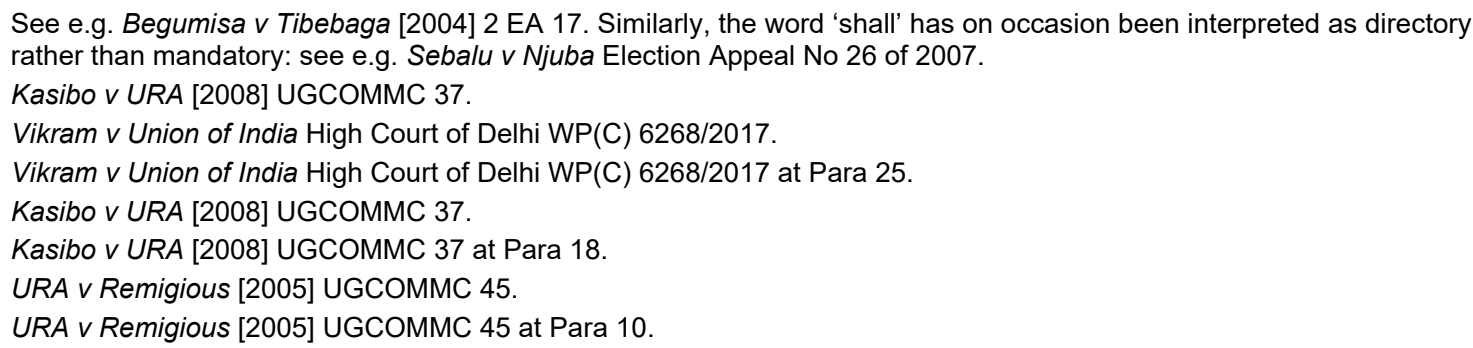


In recognition of its potential for abuse, the discretionary power to compound an offence cannot be delegated by the Commissioner General. ${ }^{48}$ Further, discretionary power to compound offences is usually tamed by guidelines. In Vikram $v$ Union of India ${ }^{49}$ the court observed that: 'The power to compound cannot be completely unbridled inasmuch as the same could give rise to enormous discretionary power, which could also lead to arbitrariness, discrimination, abuse etc. For this reason, and in order to maintain uniformity and consistency, circulars and guidelines are required to be issued for compounding of offences. Such guidelines and circulars ensure a degree of objectivity'. ${ }^{50}$ The Commissioner General's power to compound under section 66(1a) has therefore been delineated in public notices issued by URA.

\section{Discretionary VDPs in other jurisdictions}

VDPs have been considered to be discretionary in Canada. In the Canadian case of Worsfold $v$ The Minister of National Revenue, ${ }^{51}$ the court emphasised that granting of relief under the VDP was discretionary and not available as of right. The reason for this is that the taxpayer has failed to fulfil their statutory duty to be tax-compliant, and this failure does not confer a right to be excused from consequent penalties. The VDP is an exceptional relief that is accessible at the discretion of the authority, not as a right by the taxpayer. This was articulated in the Canadian case of Williams $v$ The Minister of National Revenue, where the court noted that: 'The applicant was under an obligation to comply with the requirements of the Act, and became liable for penalties when he failed to do so. The discretion accorded to the Minister to waive or cancel any penalties imposed is broad, and constitutes exceptional relief from penalties for which taxpayers are otherwise liable to pay under statute'. ${ }^{52}$

Penalties, interest and risk of prosecution exist in tax statutes as a means of deterrence from non-compliance. Creating an automatic suspension of these deterrent provisions through a VDP application undermines tax administration - which needs a stick as much as a carrot, if not more so. The value of these deterrent tax provisions was acknowledged in the Canadian case of CRA $v$ Telfer, ${ }^{53}$ in which Ms Telfer's objection to assessments was held in abeyance pending determination of a court case with similar issues. Upon conclusion of the case the objection was dismissed and accumulated interest was charged. Ms Telfer sought relief from the interest arguing that the delay was partly due to the pending case. The court rejected this argument, noting that: 'Those who, like Ms Telfer, knowingly fail to pay a tax debt pending a decision in a related case normally cannot complain that they should not have to pay interest. If they had promptly paid the sum claimed to be due, and were later found not liable to pay it, the Minister would have had to repay the overpayment, with interest. The relatively high rate of interest charged to the taxpayer is no doubt intended, for the benefit of all taxpayers, to encourage the prompt payment of tax debts'. ${ }^{54}$

The purpose of the VDP is to support statutory requirement of compliance, not to confer rights upon non-compliant taxpayers. This was well articulated by the court in Williams $v$ The Minister of National Revenue, ${ }^{55}$ where the judge stated:

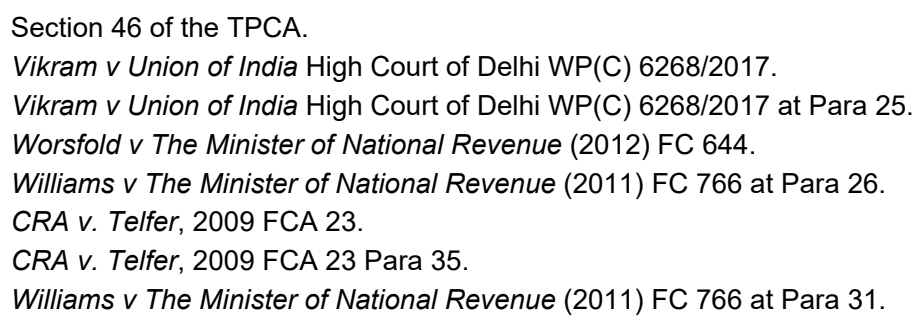


I would add that the degree of procedural fairness and the robustness by which the principle is implemented varies with the nature of the interests or rights engaged and with the nature of the discretion. The VDP is a highly discretionary programme which, as its object, encourages compliance with important mandatory statutory requirements. Put more bluntly, it is designed to encourage taxpayers to do that which they were required by law to have done in the first place. As such, the criteria governing the exercise of discretion are strict and narrow and the rights involved are minimal. ${ }^{56}$

Interpreting section 66(1a) of the TPCA in any other way risks creating an absurdity - a noncompliant taxpayer being placed in a better position than a compliant one, incentivising compliant taxpayers to become non-compliant and benefit from the VDP. If section 66(1a) is not discretionary, then a rational taxpayer would have more incentive to be non-compliant than to be compliant because they can claim an automatic right to benefit from the VDP and thereby avoid any penalties or interest. Automatic waiver of penalties and interest for every non-compliant taxpayer amounts to a reward for non-compliance. However, if section 66(1a) is interpreted as discretionary, then the non-compliant taxpayer has no guarantee that they will be able to access the penalty and interest waiver unless they meet conditions set by the Commissioner in exercise of his or her discretion.

\subsubsection{Requirements of a valid voluntary disclosure under section 66(1a)}

The URA has issued a public notice on 5 October 2020 explaining the VDP under section 66(1a). The public notice defined a voluntary disclosure and stated the requirement that it be 'in writing' and be 'complete and accurate'. It also outlined circumstances in which a voluntary disclosure would not be accepted, and laid out a procedure for applying for relief under the VDP (URA 2020c). From a reading of the law and public notice, the following are the requirements for an application to qualify for the VDP under section 66(1a):

(1) The disclosure must be voluntary.

(2) The disclosure must be complete and accurate.

(3) The disclosure must not fall within one of the exceptions.

\section{The disclosure must be voluntary}

The public notice states that: 'Voluntary Disclosure occurs when a taxpayer, unprompted and of their own volition, comes forward to disclose their tax liabilities, misstatements or omissions in their tax declarations in order to return to a fully compliant status with respect to legal obligations' (URA 2020c). The taxpayer must not have been prompted by any compliance action by URA such as: initiation of a tax investigation, request for tax information, tax advisory letter, tax health check/review, notice of audit, tax query, or compliance visit by URA officers (URA 2020c). Voluntariness of a disclosure is a key policy objective of the programme. If disclosures made by taxpayers prompted by compliance actions were to be accepted, there would be no incentive for taxpayers to correct past deficiencies until it was clear that they are going to be held accountable. ${ }^{57}$ The requirement of voluntariness is in line with the model tax amnesty decribed earlier.

Whether a disclosure has been prompted by a compliance action is a question of fact and can be determined by examining the circumstances in which it was made. In the Canadian case of Worsfold $v$ The Minister of National Revenue, ${ }^{58}$ the applicant was a shareholder and director in a company. The applicant's VDP application relating to his personal affairs was

Williams $v$ The Minister of National Revenue (2011) FC 766 at Para 31.

334156 Alberta Ltd v Canada (Minister of National Revenue), 2006 FC 1133.

Worsfold $v$ The Minister of National Revenue (2012) FC 644. 
filed an hour after the CRA notified the company of an impending audit. There was evidence that the applicant had been contemplating a VDP application for several months and had even discussed it with tax lawyers. The court considered that the chain of events showed that the VDP application was not prompted by the impending company audit.

The fact that a taxpayer does not perceive a particular action by URA as a compliance action is irrelevant where a reasonable person would perceive it as such. In the Canadian case of Williams $v$ The Minister of National Revenue, ${ }^{59}$ the applicant, a non-filer, had been in contact with the Non-Filer Division of the CRA for several years. When his VDP application was rejected, he argued that he did not perceive the notices to file an income tax return as enforcement activity. Court upheld the rejection, noting that, "[a] reasonable person would conclude, having regard to the extent of non-compliance, the repeated issuance of Notices to File and the communications with the Non-Filers Division of CRA that enforcement activity was underway'. 60

In order to preclude a voluntary disclosure, compliance action must relate to the tax type and tax period being disclosed. The public notice states: 'A taxpayer who is subject to ongoing compliance action in respect of a tax head and a particular tax period may nonetheless make voluntary disclosure in relation to a different tax head in the same or different period or the same tax head in a different period provided that the information that is disclosed would not inevitably have been discovered by the ongoing compliance action' (URA 2020c). Therefore, a taxpayer who is under audit for say, non-remittance of employee payroll deductions, may make a valid voluntary disclosure relating to VAT provided that there is no correlation between the two taxes. This is a question of fact. Where there is a link between the two taxes, the VDP may be rejected. In Robinson v Her Majesty the Queen, ${ }^{61}$ the CRA notified the applicant of an impending employee payroll audit. The applicant made a VDP application with respect to unpaid income tax and goods and services tax (GST). The court upheld the rejection of the VDP application because the applicant failed to show that the payroll audit would not have disclosed the non-filings in income tax and GST.

\section{The disclosure must be complete and accurate}

The requirement that a voluntary disclosure be complete and accurate stems from the requirement that taxpayer declarations to the URA be complete and accurate. ${ }^{62}$ In the Canadian case of Palonek $v$ The Minister of National Revenue, ${ }^{63}$ the CRA rejected a VDP application on grounds of incompleteness. This rejection was upheld by the court, which noted that the taxpayer's duty to submit complete information was 'not different from the duty that any taxpayer has with respect to income tax returns, i.e. full disclosure of all income from all sources'. ${ }^{64}$ Accordingly, an applicant should not limit the disclosure to select errors or omissions or to specific taxation years or reporting periods. The VDP is premised on the idea of a fresh start for the taxpayer. Allowing incomplete disclosure would enable a taxpayer to cherry-pick instances of non-compliance where they fear discovery, and ignore instances where they think discovery is less likely.

Where the VDP application is deliberately incomplete in some material aspect, the partial disclosure may be used by the URA to assess the taxpayer and levy penalties or initiate

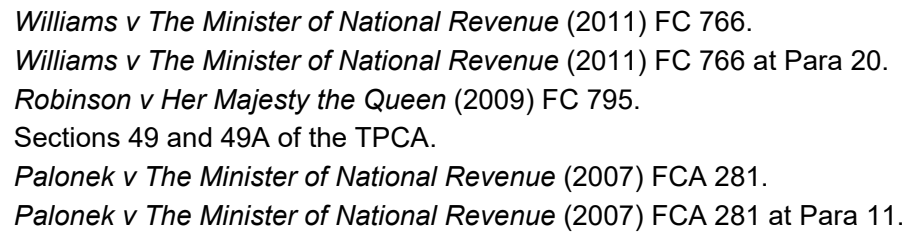


prosecution for non-compliance. In the US case of Shotwell Mfg. Co. $v$ United States ${ }^{65}$ the executives of a company made a VDP application in 1948 disclosing failure to pay taxes. However, it was subsequently discovered that the disclosure was incomplete and they were prosecuted for tax evasion. Part of the evidence used against them came from their purported disclosure, and they objected to this as contrary to the right against selfincrimination. Upon appeal, the Supreme Court held that no bona fide honest disclosure had ever been made, and the purported disclosure was a further effort to perpetrate a fraud on the government, therefore admission of the evidence so obtained did not violate petitioners' privilege against self-incrimination. The court observed that: 'What is involved here is not a case of incriminatory evidence having been induced by the Government, but one in which petitioners attempted to hoodwink the Government into what would have been a flagrant misapplication of its voluntary disclosure policy'. ${ }^{66}$

The VDP application ought to cover all relevant tax heads where there has been noncompliance. In the Kenyan case of Awal Limited $v$ Commissioner of Investigations and Enforcement ${ }^{67}$ the appellant, while under investigation for VAT, made a voluntary disclosure regarding income tax. The VAT investigations uncovered additional invoices that had not been declared as part of the VDP application. Court held income from the sale of goods subjected to VAT ought to have been disclosed as part of the VDP application, which was therefore incomplete. Findings on investigation on VAT therefore had effect on income declared.

\section{The disclosure must not fall within the listed exceptions}

A number of circumstances in which a VDP application will not be accepted are listed in the public notice (URA 2020). These exceptions focus on excluding information that the URA was already aware of, or that is easily discoverable. In the South African case of Purveyors $v$ SARS, ${ }^{68}$ Purveyors was liable for import VAT in 2015 but failed to report and remit such amounts of VAT to SARS. In 2016, Purveyors engaged with SARS conveying no more than a broad overview of the facts. In February 2017 SARS advised Purveyors that they had to pay the tax with penalties. Purveyors subsequently applied to SARS under the VDP arguing that it had received no notice of audit or investigation therefore the application was voluntary, despite SARS' prior knowledge of the issue. SARS argued that the disclosure must be of information or facts of which SARS had been unaware. Court held that: 'the purpose of the VDP provisions is to incentivise errant taxpayers to come clean. That purpose would be defeated if the only circumstance under which a VDP application were to be held as involuntary was the receipt of a notice of an audit... When applicant made the VDP application it was obviously aware that SARS knew of its default. It in fact disclosed nothing new the application was therefore not a valid one. There can be no disclosure to a person if the other already has knowledge thereof: certainly not in the present statutory context'. ${ }^{69}$ The application of the VDP should therefore be done with consideration of its purpose, which is encouraging the previously non-compliant to become compliant. The following are the lists of exceptions to the Ugandan VDP.

(a) Principal tax The VDP remission does not apply to the principal tax due, as it remains due and payable even when the VDP application has been accepted. This is in accordance to section 67 of

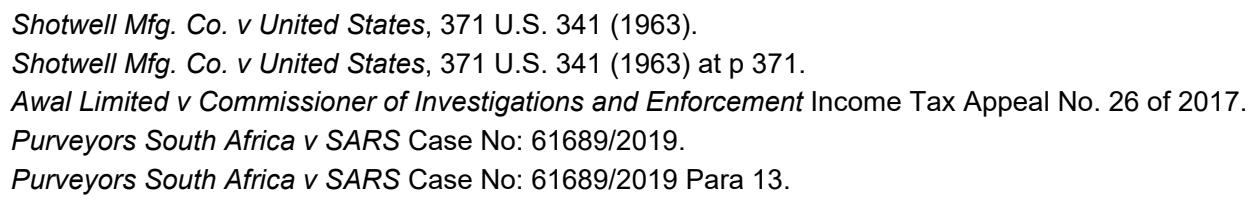


the TPCA, which provides that the amount of any tax due and payable under a tax law by a taxpayer is not abated by reason only of the compounding of such offence under section 66 .

(b) Penalties and interest already assessed

Where interest and penalties have already been assessed by the URA, a VDP application is not possible. This exclusion would apply even when the taxpayer was not aware that penalties and interest had already been assessed - for example, where communication has been made to a registered email address that the taxpayer had ceased to use. ${ }^{70}$ This is because the application would no longer be considered necessary as the URA has already detected the non-compliance, and issued interest and penalties in that regard.

(c) Disclosure that relates to routine errors

A disclosure relating to routine errors, such as arithmetical errors, which would routinely generate an assessment even if not disclosed, is not considered a voluntary disclosure (URA 2020c). This stems from an understanding of the VDP as an exceptional compliance effort that supports other efforts at compliance, and not a means of allowing taxpayers avoid obvious liabilities.

(d) Where information is in the public domain

The public notice excludes from voluntary disclosures 'information available in the public domain regarding the specific taxpayer's or a related taxpayer's potential involvement in tax non-compliance'. There have been instances in which URA has relied on information in the public domain to assess taxes. In 2016 URA relied on information revealed during a fraud case filed by the telecom giant, MTN, against some of its staff to issue a four-year tax assessment (The East African 2017). URA relies on information in newspapers and lifestyle magazines in identifying and assessing HNWIs (Kangave et al. 2018). This exclusion can be presumed to apply to such information as well. This exclusion is premised on the fact that the URA would have detected the non-compliance without a disclosure by the taxpayer.

(e) Where an associate of the taxpayer is under audit or investigation

A VDP application will be rejected where an associate of the applicant is under audit or investigation and that audit or investigation would inevitably have led to what is being disclosed (URA 2020c). An associate is defined under the tax laws as 'any person, not being an employee, who acts in accordance with the directions, requests, suggestions, or wishes of another person'. ${ }^{71}$ Where a person, either alone or together with an associate or associates, controls 50 per cent or more of the voting power in a company, they are associates of that company. ${ }^{72}$ This exclusion applies because the associate is presumed to be aware of the audit, and therefore of the fact that their non-compliance is about to be discovered.

This particular exclusion will be challenging to operationalise. A taxpayer may not necessarily be aware of a compliance action against an associate. Where a company is part of a large group of companies, it is possible that management of one company may not have knowledge of, or regular interaction with, other associated companies. In Canada, it has been held that the mere existence of a relationship is not sufficient to support an inference that information of an impending or ongoing compliance action against an associate was communicated to the applicant. The facts must clearly suggest that this communication did in fact take place, prompting the VDP application. ${ }^{73}$

\footnotetext{
Section 16(1) of the Electronic Transactions Act, 2011.

Section 3(1) of the Income Tax Act.

Section 3(2)(e) of the Income Tax Act.

Charky v Attorney General of Canada 2010 FC 1327.
} 
Further, determining that particular information would inevitably have been discovered is difficult. The link between the compliance action against one company and information disclosed by a related company must be clear and should not involve speculation in order for it to be rejected. In AIMO v The Attorney General of Canada, ${ }^{74}$ the CRA entered the name of a company that was a shareholder of AIMO into its electronic registry of companies to be audited, with a focus on withholding of tax on dividends paid to it, which AIMO had not been doing. AIMO's sole director was aware of the impending shareholder's audit. A few months later AIMO applied under VDP disclosing its failure to remit taxes on dividend payments. CRA rejected it on grounds that the enforcement action against AIMO's shareholders was likely to have uncovered the information disclosed. Court held that the link between the intended audit and AIMO's disclosure was tenuous, and it required speculation to conclude that the actions taken against the shareholder would have led to the discovery of AIMO's non-compliance.

The mere fact that a VDP applicant is a director in a company that has been notified of an impending audit does not invalidate the application. First it would have to be proven that as a director they were made aware of the impending company audit, and second it would have to be shown that information disclosed would inevitably have been discovered by the audit. In 4053893 Canada Inc $v$ The Minister of National Revenue, ${ }^{75}$ the sole owner of the appellant company had been non-compliant in filing his personal tax return. In 2016 the CRA communicated with him regarding this non-compliance, during which he mentioned that his company was still active. In 2017, the company applied under VDP, but CRA rejected it because of the earlier communication. Court rejected the CRA's argument, noting that the mere existence of a relationship between taxpayers was insufficient. The CRA had to address how enforcement action against one taxpayer would likely uncover information that is the subject of voluntary disclosure by another taxpayer. The fact that the director was the sole owner of the company was considered inadequate. In Poon v Her Majesty the Queen ${ }^{76}$ a company, APS received a notification to file returns. Subsequently, its director made a voluntary disclosure application regarding his personal income earned from APS and other sources. The court overturned the CRA's rejection of his VDP application because it could not explain how enforcement action against APS would have led to discovery of what was disclosed.

It is therefore submitted that, as in Canada, this exclusion should be interpreted narrowly the URA should be required to establish how they would have discovered the noncompliance of the applicant through investigation or audit of the associate.

\subsubsection{Procedure of applying for the VDP}

The taxpayer applies by filling in a Voluntary Disclosure Form (VDF), admitting to the offence and requesting to be considered under the VDP. The VDF may be completed and signed by the taxpayer, ${ }^{77}$ tax representative ${ }^{78}$ or tax agent. ${ }^{79}$ The VDF requires the applicant to submit details identifying them, including their name and Taxpayer Identification Number.

Anonymous VDP applications where the taxpayer only reveals themselves after a guarantee of acceptance could be problematic. Anonymous disclosures may be subject to abuse by advisors making generic disclosures without an underlying taxpayer, and subsequently holding these in inventory to be used later if a client with similar deficiencies became a

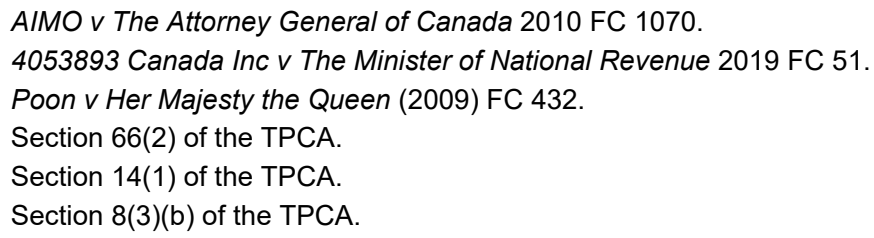


subject of audit. That way they could claim that the date of the disclosure was prior to the audit, an occurrence that took place in Canada, leading to a revision of the procedures relating to no-name disclosures (Friedman 2016). Anonymous disclosures also create room for unnecessary litigation over the VDP, as the URA may inadvertently accept VDPs of taxpayers whose non-compliance they are already aware of. ${ }^{80}$ Upon submission of the application, it is reviewed and subsequently accepted or rejected. Where it is accepted, the applicant receives a Voluntary Disclosure Certificate signed by the Commissioner General. There are no timelines given in which the VDP application is to be considered.

\section{Strengths of the Ugandan VDP}

Unlike previous amnesties, this is a permanent VDP in line with the model tax amnesty previously described. Taxpayers in Uganda generally have little trust in the URA (Ali et al. 2014). Despite considerable efforts to build a better working relationship and trust with the citizens, a lot remains to be done (The Observer 2020). In this low-trust environment, it will take time to convince the public that the VDP is a genuine compliance measure from which they can benefit. Taxpayers may be afraid, and perceive the measure as a ruse to get noncompliant people to reveal themselves. This lack of trust in the tax authority reportedly contributed to underpeformance of the 2018 Ghanaian temporary tax amnesty (CNBC Africa 2019). A time-bound amnesty does not allow time to build trust that the VDP is actually being administered as communicated.

In line with the model tax amnesty, the Ugandan VDP is accompanied by other compliance and enforcement measures. First, renewed effort has been made to combat corruption in the tax revenue authority since early 2020 (The Independent 2020; The Observer 2020a).

Reducing the likelihood of corruption as a means of escaping liability will encourage voluntary compliance through the VDP. Second, URA has introduced new compliance mechanisms, such as Digital Tax Stamps (DTS) and the Electronic Fiscal Receipting and Invoicing System (EFRIS). DTS were launched in November 2019, and are used to track and trace goods subject to excise duty and to combat illicit trade in contraband goods (The Independent 2019; URA 2020b). EFRIS will be used by URA to monitor transactions of VATregistered taxpayers; it will be launched in January 2021 (Asingwire 2020). These compliance measures support the VDP by increasing the possibility of detection, thereby encouraging taxpayers to take advantage of the VDP.

The Ugandan tax amnesty requires the taxpayer to voluntarily disclose their non-compliance, and is not available to those who do not disclose and those whose non-compliance is already known to the tax authority. This is in line with the model tax amnesty. As already noted, some previous amnesties in Uganda, such as the one in 2008, were blanket amnesties, applicable to all taxpayers without the need for any action on their part. The current VDP requires taxpayers to disclose their non-compliance to the URA, allowing for intelligence- and datagathering that may be useful when designing future compliance initiatives. Taxpayers whose non-compliance is already known are excluded, because the URA is able to recover that tax, interest and penalties owed. The Ugandan VDP does not accept anonymous disclosures, which is in line with the model tax amnesty.

Further in line with the model tax amnesty, the Ugandan VDP grants relief for the taxpayer from prosecution, penalties and interest. The principal tax owed remains due and payable, and is explicitly excluded by the public notice. Relief from prosecution is an important relief, 
because tax offences contain a criminal element and are prosecutable. Granting relief from penalties and interest alone, without including the principal tax owed, is helpful. Relief from the unpaid principal amount owed would likely be perceived as unfair by compliant taxpayers, and could incentivise non-compliance.

The URA has put considerable effort into communicating the VDP to the public. Following the public notice issued on 5 October 2020, the URA has continued to engage with the public on the subject through social media, webinars and mainstream media. The URA Commissioner General continues to highlight the VDP in virtually every public appearance, noting that it is available to all taxpayers who meet the conditions publicised.

\section{Limitations of the Ugandan VDP and recommendations}

\subsection{Use of public notices instead of practice notes}

The details relating to administration of the VDP have been communicated to the public through public notices in newspapers and on the URA website, instead of through practice notes. Practice notes are communications from the URA that are published in the Gazette, setting out the Commissioner's understanding of the application of a provision in a tax law. ${ }^{81}$ Crucially, practice notes are provided for by the TPCA, and are binding on the Commissioner until they are revoked. ${ }^{82}$ As already observed, during the 2007 tax amnesty, the URA issued a practice note laying out details of how the amnesty would be administered (URA 2007). Public notices, on the other hand, have no statutory basis, and are usually used to communicate general information to the public, such as reminders. While it is likely that courts would find such public notices binding on URA in certain circumstances, based on the common law doctrines of estoppel and legitimate expectation, ${ }^{83}$ the use of a practice note would inspire more confidence in the public that URA will be bound by its communication (Becker et al. 2020).

In line with the principle of clear communication in the model tax amnesty developed in section 4, it is recommended that URA issue a practice note laying out the procedure for administration of the VDP. This would increase trust among taxpayers that the VDP is a genuine compliance measure, and that they can benefit from it.

\subsection{Secret investigations}

It remains unclear what happens where an investigation or audit is ongoing in the URA, but the taxpayer has not yet been notified. In certain instances, such as where there is a risk that a taxpayer may destroy evidence of non-compliance, URA may be compelled to carry out secret investigations without informing the taxpayer. If the taxpayer makes a VDP application in such circumstances, the outcome remains unclear. Where considerable manpower and effort has been expended in an ongoing secret investigation, it would seem absurd to allow a taxpayer to escape prosecution, penalties and interest by applying under a VDP. On the other hand, the taxpayer's right to procedural fairness and the need to generate public trust

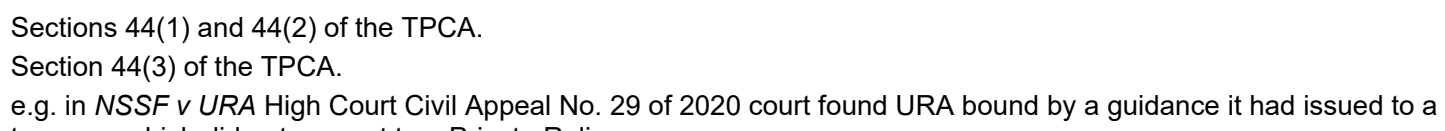


in the VDP would suggest it might be better to accept the application. Courts in the US regularly hold that no valid VDP application occurs when there is an ongoing investigation, even if the taxpayer is unaware of it. In Lapides $v$ United States ${ }^{84}$ the taxpayer voluntarily disclosed his unreported income in May 1951, but, unbeknownst to him, the tax authority had assigned an officer to undertake a preliminary investigation of his affairs in April of the same year. The court held that the VDP application was not valid stating: 'The mere fact that the Department did not inform him and that he did not know that an investigation had been begun was irrelevant... For the issue as to the timeliness of the disclosure depended, as pointed out above, on the fact of a prior investigation, not on the appellant's absence of knowledge or belief as to that fact'.

Similarly, in White $v$ United States ${ }^{85}$ the taxpayer disclosed his fraud when an investigation into his tax affairs had already commenced without his knowledge. The court rejected the validity of the voluntary disclosure, because it was made after the investigation was underway. ${ }^{86} \mathrm{~A}$ similar view was held in other cases. ${ }^{87}$

It is recommended that the list of exclusions from the VDP be amended to include situations where the URA can prove that it was conducting investigations. The burden of proof must remain on the tax authority to prove that it was indeed conducting these investigations, and that non-compliance would have been discovered. This approach is recommended because it is generally elaborately designed tax evasion schemes that necessitate secret investigations.

\subsection{VDP does not cater for different forms of non-compliance}

As described in part 1, various segments of the population engage in different forms of noncompliance for different reasons. HNWls, multinational entities and large local corporations generally engage in intentional non-compliance. These firms can afford to hire some of the best tax experts in the country - their non-compliance is often intentional, and may involve considerable efforts on their part to avoid detection. On the other hand, taxpayers in the informal sector may engage in non-compliance due to limited knowledge of the tax regime, including a lack of understanding of their actual liability and how to become compliant (Joshi et al. 2014).

The Ugandan VDP does not distinguish between these two broad groups of taxpayers. The same relief is available to taxpayers who engage in non-compliance intentionally and to those who are non-compliant due to limited knowledge of the tax regime. This is unfair to the compliant taxpayers and appears to reward intentional non-compliance.

It is therefore recommended that the Ugandan VDP be transformed into a two-stream VDP, similar to the new Canadian VDP. Taxpayers with a gross turnover of USh35 billion or more who take advantage of the VDP can benefit from non-prosecution and a waiver of penalties, but have to pay interest due. Taxpayers with a gross turnover below USh35 billion who take advantage of the VDP can have the same relief and benefit from an interest waiver. Other factors, such as the extent to which non-compliance was intentional, and efforts involved in avoiding detection, can also be considered. This would make the VDP more equitable in line with the model tax amnesty developed in section 3 of this paper.

Lapides $v$ United States, 215 F.2d 253 (1954).

White $v$ United States, 194 F.2d. 215 (5th Cir. 1952).

White $v$ United States, 194 F.2d. 215 (5th Cir. 1952) at Para 10.

United States v Levy, 99 F. Supp. 529 (1951) and United States v Lustig, 163 F.2d 85 (2d Cir. 1947). 


\subsection{VDP's interaction with other laws remains unclear}

Tax non-compliance may sometimes involve breaching other legislation. Offences in the Penal Code Act, such as conspiracy to defeat a tax law ${ }^{88}$ and making false documents, ${ }^{89}$ may be committed in an effort to evade taxes. In such instances the compounding of the tax offence under the TPCA would seem to cover these offences under the Penal Code Act under the rule against double jeopardy..$^{90}$

However, there may be instances where the secondary offence is operated by a different authority. For example, taxpayers engaging in tax evasion may also be in breach of the AntiMoney Laundering Act, 2013, which is operated by the Financial Intelligence Authority. A bank's tax non-compliance may also involve non-compliance in its reporting requirements to its regulator, Bank of Uganda. In such an instance, while the bank is able to avoid prosecution, interest and penalties for tax non-compliance under the VDP, it risks heavy penalties if the information is shared with the regulator. Similarly, tax practitioners who may have aided in the non-compliance may be afraid of being reported to their regulatory bodies and penalised for unethical behaviour if their activities are revealed in a VDP application. They also risk being deregistered from the list of tax agents recognised by the URA under the TPCA. ${ }^{91}$ The current VDP mechanism does not shield them from this. This is not just an academic question. When tax amnesties were first offered in South Africa, many tax practitioners advised taxpayers not to apply on the grounds that there was no exemption from penalties under their Financial Intelligence Centre Act, which would have penalised the tax advisors. An exemption was subsequently published and the tax amnesty picked up (Junpath et al. 2016).

The URA can commit not to share any of the information that is submitted under the VDP. The duty of confidentiality for tax information can be relied on for this. ${ }^{92}$ However, this may not be sufficiently reassuring. It is therefore recommended that an exemption similar to that in South Africa be offered, such that beneficiaries of the VDP do not risk penalties from other public bodies.

\subsection{Absence of timelines}

There is no timeline within which URA is required to respond to the submission of a VDF. This is a challenge, as it creates uncertainty for taxpayers as they await the outcome of their application. A clear timeline within which to expect a response is necessary.

There is also no clear timeline for the conclusion of an audit or other compliance action. This may create a challenge in determining whether or not a VDP application can be made. For example, a taxpayer may receive a request for information from URA and submit it. After six months the taxpayer may not have received any follow-up from URA regarding the information submitted. The taxpayer would be unsure whether or not they can submit a VDP application relating to the same information. It needs to be clarified that where URA has lost interest in a particular compliance action by not following up on it for a period of time, such as six months, the taxpayer can make a valid VDP application.

\footnotetext{
88 Section 392(a) of the Penal Code Act Cap 120 applied in Basajabalaba v Kakande [2013] UGHCCRD 19.

89 Section 345 of the Penal Code Act Cap 120; See for example Ndimwibo v URA [2017] UGCOMMC 39.

90 Article 28(9) of the Constitution of the Republic of Uganda, 1995.

91 Section 13(3)(d) provides that the Tax Agent Registration Committee may deregister a tax agent who prepares tax returns that are false in material particulars.

Section 47 of the TPCA.
} 
Finally, there are no timelines to cater for a situation where the taxpayer is required to submit documents when the original VDP application has insufficient information. The Canadian VDP provides for 90 days within which to submit any additional documents. It is recommended that URA adopts a clear timeline within which to submit additional documents.

\subsection{Allowance for minor errors}

There is no provision for a situation where the taxpayer makes a minor error in their VDP application that is subsequently discovered through an audit. A VDP application must be complete and accurate in order to be valid. Where it is subsequently discovered that the application contained inaccuracies, the Voluntary Disclosure Certificate will be revoked. However, it is possible for a taxpayer to make minor errors in their VDP application that may subsequently be discovered. Such errors ought not to result in a revocation of the Voluntary Disclosure Certificate.

In Canada, minor omissions or deficiencies in the completeness of a disclosure will not, in and of themselves, render the disclosure invalid. However, if the disclosure is found to contain 'substantial errors or omissions', the disclosure may not qualify as a valid disclosure. In these cases, what constitutes a substantial error is to be determined on a case-by-case basis' (Friedman 2016). It is recommended that URA adopt a similar approach.

\subsection{VDP applications that result in a refund position}

The public notice is silent on situations where the VDP application places the taxpayer in a refund position. A taxpayer might have undisclosed income from transactions that are zerorated for the purposes of VAT. The taxpayer could make a VDP application ostensibly of the undisclosed income; however, the zero-rated transactions could place the taxpayer in a net refund position. The taxpayer could have been put off from claiming this refund by the penalties and interest that would accrue, which the acceptance of the VDP would do away with.

One of the main purposes of the VDP is to raise revenue, therefore applications that result in refund positions ought to be excluded. As previously noted, the South African VDP explicitly excludes applications that result in a refund position. It is recommended that the URA adopt this position, making VDP applications that place the taxpayer in a refund position invalid.

\subsection{Repeated VDP applications}

The public notice does not have a limit on the number of VDP applications that a taxpayer can make. This leaves the programme open to abuse - similar in nature to that of repeated tax amnesties inadvertently encouraging non-compliance, where the taxpayer deliberately engages in evasion because they intend to benefit from a VDP.

It is recommended that taxpayers be allowed to make only one VDP application, after which they cannot be allowed to make another application except where they could not have discovered the non-compliance before the initial VDP. The VDP should be understood as a quid pro quo arrangement, where the URA offers relief from penalty and interest, and the taxpayer makes a bona fide effort to analyse their historical tax affairs to identify and disclose all instances of non-compliance. The taxpayer making the VDP application has the duty to make all inquiries that a reasonable person would make to determine that all previous deficiencies in reporting have been discovered and are disclosed. Such an approach can be adopted through issuance of a practice note to that effect, without a need to amend section $66(1 a)$ of the TPCA. 


\section{Conclusion}

Tax amnesties have been used around the world with varying degrees of success. While they have significant benefits, they come at the risk of considerable costs. The model amnesty developed in section 3 attempts to ensure the benefits of the amnesty are maximised and the costs are minimised. The Ugandan VDP is an innovative approach to taxpayer compliance. The current VDP presents a useful opportunity for those engaged in evasion and other forms of non-compliance to rectify their status. It provides a permanent tax amnesty for the largely non-compliant population. It matches up to the model tax amnesty in a number of ways. However, as currently designed, the Ugandan VDP has a number of limitations that need to be dealt with for the benefits to be maximised and the costs minimised. More research is needed to assess the benefits of the VDP through empirical analysis of data. 


\section{References}

Adams, C. (2001) For Good and Evil: The Impact of Taxes on the Course of Civilization, Madison Books

ADBG (2010) Domestic Resource Mobilization for Poverty Reduction in East Africa: Uganda Case Study, retrieved from Regional Department East A (OREA), www.afdb.org/fileadmin/uploads/afdb/Documents/Project-andOperations/Uganda\%20case \%20study\%20final.pdf

Akol, D. (2015) 'Informal sector is threat to tax revenue collection', retrieved from The Observer, 13 May 2015, www.observer.ug/viewpoint/37810-informal-sector-is-threatto-tax-revenue-collection

Ali, M., Fjeldstad, O-H. and Sjursen, I. (2014) 'To Pay or Not to Pay?: Citizens' Attitudes Toward Taxation in Kenya, Tanzania, Uganda, and South Africa', World Development 64: 828-842

AlJazeera (2017) 'What are the 'Paradise Papers' and why should you care?', 6 November 2017, retrieved from www.aljazeera.com/economy/2017/11/06/what-are-the-paradisepapers-and-why-should-you-care/

Alm, J. and Beck, W. (1991) 'Wiping the Slate Clean: Individual Response to State Tax Amnesties', Southern Economic Journal 57(4): 1043-1053

Almunia, M., Gerard, F., Hjort, J. and Knebelmann, J. (2015) Fiscal Capacity and Tax Revenues in Uganda, International Growth Centre Working Paper S-43118-UGA-1

Asingwire, N. (2020) 'URA extends deadline for taxpayers to integrate electronic invoicing and receipting system', 26 September 2020, retrieved from Kampala Post, https://kampalapost.com/index.php/content/ura-extends-deadline-taxpayers-integrateelectronic-invoicing-and-receipting-system

ATO (2012) Miscellaneous Taxation Ruling MT 2012/3 Administrative penalties: voluntary disclosures, 9 May 2012, retrieved from www.ato.gov.au/law/view/document?Docid=MXR/MT20123/NAT/ATO/00001

(2008) Miscellaneous Taxation Ruling MT 2008/3 Shortfall penalties: voluntary disclosures, 12 November 2008, retrieved from www.ato.gov.au/law/view/document?docid=MXR/MT20083/NAT/ATO/00001\&PiT=200 81112000001

- (1994) Taxation Ruling TR 94/6 Income tax: tax shortfall penalties: voluntary disclosures, 6 January 1994, retrieved from www.ato.gov.au/law/view/document?docid=TXR/TR946/NAT/ATO/00001\&PiT=199401 06000001

Baer, K. and Borgne, E. (2008) Tax Amnesties: Theory, Trends, and Some Alternatives, Washington DC: IMF 
Barone, G. and Mocetti, S. (2009, November). Tax morale and public spending inefficiency, Bank of Italy Temi di Discussion Working Paper No. 732, http://ssrn.com/abstract=1601924

Bayer, R-C., Oberhofer, H. and Winner, H. (2015) 'The occurrence of tax amnesties: Theory and evidence', Journal of Public Economics 125@: 70-82

BBC (2016) Panama Papers: How Jersey-based oil firm avoided taxes in Uganda, 8 April 2016, retrieved from www.bbc.com/news/world-africa-35985463

Becker, C., Karugaba, P. and Kenyangi, A. (2020) 'Uganda Revenue Authority Issues Public Notice on Voluntary Disclosure under the Tax Procedures Code Act', 31 August 2020, retrieved from Mondaq, www.mondaq.com/tax-authorities/979590/uganda-revenueauthority-issues-public-notice-on-voluntary-disclosure-under-the-tax-procedures-codeact

Blackwell, R. (1980) 'Supplement: Criminal Prosecution - Voluntary Disclosure; History, Revocation and Revival', William \& Mary Annual Tax Conference, 125

Borgne, E. (2006) Economic and Political Determinants of Tax Amnesties in the U.S. States, IMF Working Paper 06/222

Chiringa, K. (2018) 'Inland revenue collects N\$300 million as third tax amnesty deadline ends .... Fails to get the envisaged N\$4 billion', 6 April 2018, retrieved from The Villager, www.thevillager.com.na/articles/12903/inland-revenue-collects-n300-million-as-thirdtax-amnesty-deadline-ends-fails-to-get-the-envisaged-n4-billion/

Christian, C. and Gupta, S. (2002) 'Evidence on Subsequent Filing from the State of Michigan's Income Tax Amnesty', National Tax Journal, 55(4): 703-721

CNBC Africa (2019) Assessing Ghana's tax amnesty policy, 19 March 2019, retrieved from www.cnbcafrica.com/videos/2019/03/19/assessing-ghanas-tax-amnesty-policy/

CRA (2017) IC00-1R6 Voluntary Disclosures Program, December, retrieved from www.canada.ca/content/dam/cra-arc/formspubs/pub/ic00-1r6/ic00-1r6-e.pdf

(2007) IC00-1R2 Voluntary Disclosures Program, 22 October 2007, retrieved from http://cra2011.cutetax.ca/E/pub/tp/ic00-1r2/ic00-1r2-lp-e.pdf

Crabbe, V. (1994) Understanding Statutes, Cavendish Publishing Ltd.

Dare, C., Jansen, A. and du Plessis, S. (2018) Taxpayers' behavioural responses to Voluntary Disclosure Programmes: evidence from South Africa, ERSA working paper 771

EY (2018) Namibia extends tax amnesty program to 3 April 2018, 19 March 2018, retrieved from EY Global Tax Alert:

www.ey.com/Publication/vwLUAssets/Namibia_extends_tax_amnesty_program_to_3_ April_2018/\$FILE/2018G_01641-

181Gbl_Namibia\%20extends\%20tax\%20amnesty\%20program $\% 20$ to\%203\%20April\% 202018.pdf 
Farrar, J. and Hausserman, C. (2016) 'An Exploratory Investigation of Extrinsic and Intrinsic Motivations in Tax Amnesty Decision-Making', Journal of Tax Administration 2:2

Feige, E. and Cebula, R. (2011) America's unreported economy: measuring the size, growth and determinants of income tax evasion in the U.S., MPRA Paper 34781

Fisher, R., Goddeeris, J. and Young, J. (1989) 'Participation in Tax Amnesties: The Individual Income Tax', National Tax Journal 42(1): 15-27

Friedman, M. (2016) Voluntary Disclosures: Navigating a Program in Transition, retrieved from Canadian Tax Foundation: https://mcmillan.ca/webfiles/CTF\%20-

$\% 20$ Voluntary\%20Disclosures_\%20Navigating\%20a\%20Program\%20in\%20Transition $\% 20 \% 20$ (Paper).pdf

Gardner, D., Lockwood, K. and Pienaar, J. (2020) Uganda's Housing Construction and Housing Rental Activities: Housing Economic Value Chain and Housing Cost Benchmarking Analysis, retrieved from Centre for Affordable Housing Finance in Africa : http://housingfinanceafrica.org/app/uploads/UGANDA-FINAL-formatted-version-1.pdf

Global Financial Integrity (2018, September) A Scoping Study of Illicit Financial Flows Impacting Uganda, retrieved from www.gfintegrity.org/wpcontent/uploads/2018/10/Uganda-Report-2018_12.20.18.pdf

Grilli, S. (2015) 'The Italian Voluntary Disclosure', retrieved September 15, 2020, from Insights, http://publications.ruchelaw.com/news/2015-04/Vol_2_No_04_01GuestArticle-ItalyVD.pdf

IRS (2020) IRS Criminal Investigation Voluntary Disclosure Practice, retrieved from Internal Revenue Service, www.irs.gov/compliance/criminal-investigation/irs-criminalinvestigation-voluntary-disclosure-practice

(2019) IRS releases new Tax Gap estimates; compliance rates remain substantially unchanged from prior study, 26 September 2019, retrieved from IR-2019-159: www.irs.gov/newsroom/irs-releases-new-tax-gap-estimates-compliance-rates-remainsubstantially-unchanged-from-prior-study

Jenkins, G. P., Kuo, C.-Y. and Shukla, G. P. (2000) Tax Analysis and Revenue Forecasting: Issues and Techniques, retrieved from Harvard Institute for International Development (Harvard University), http://jdintl.econ.queensu.ca/publications/qed_dp_169.pdf

Joshi, A., Prichard, W. and Heady, C. (2014) 'Taxing the Informal Economy: The Current State of Knowledge and Agendas for Future Research', The Journal of Development Studies 50(10): 1325-1347

Junpath, S., Kharwa, M. and Stainbank, L. (2016) 'Taxpayers' attitudes towards tax amnesties and compliance in South Africa: an exploratory study', South African Journal of Accounting Research 30(2): 97-119, http://dx.doi.org/10.1080/10291954.2015.1070565

Kangave, J., Nakato, S., Waiswa, R., Nalukwago, M. and Zzimbe, P. (2018) What Can We Learn from the Uganda Revenue Authority's Approach to Taxing High Net Worth Individuals?, ICTD Working Paper 72, Brighton: Institute of Development Studies 
and Zzimbe, P. (2016) Boosting Revenue Collection through Taxing High NetWorth Individuals: The Case of Uganda, ICTD Working Paper 45, Brighton: Institute of Development Studies

Kilonzo, T. (2012) The Effects of Tax Amnesty on Revenue Growth in Kenya, A Research Project Submitted in Partial Fulfilment of the Requirement for the Award of the Degree of Master in Business Administration, Nairobi, Kenya: University of Nairobi

Lakuma, C. (2019) Income Tax Evasion in Uganda, EPRC Research Series No. 149

- and Sserunjogi, B. (2018) The Value Added Tax (VAT) Gap Analysis for Uganda, retrieved from EPRC Research Series No 145:

https://media.africaportal.org/documents/145_Value_Added_Tax_Analysis_Uganda.pdf

Larnyoh, M. (2019) 'Ghana Revenue Authority fails to meet the Tax Amnesty Policy target of GHC500 million', 18 March 2019, retrieved from Pulse,

www.pulse.ng/bi/finance/ghana-revenue-authority-fails-to-meet-the-tax-amnesty-policytarget-of-ghc500-million/ggb9j2e

Leal, T., Pérez, J. and Tujula, M. (2007) Fiscal forecasting lessons from the literature and challenges, retrieved from European Central Bank Working Paper Series No 843/December 2007, www.ecb.europa.eu/pub/pdf/scpwps/ecbwp843.pdf

Lederman, L. (2012) 'The Use of Voluntary Disclosure Initiatives in the Battle against Offshore Tax Evasion', Villanova Law Review 57(3): 499-528

Leonard, H. and Zeckhauser, R. (1987) 'Amnesty, Enforcement, and Tax Policy', Tax Policy and the Economy 1: 55-85

Luitel, H. (2014) Is Tax Amnesty a Good Tax Policy?: Evidence from State Tax Amnesty Programs in the United State, Lexington Books

Madison, A. (2001) 'An analysis of the IRS's Voluntary Disclosure Policy', The Tax Lawyer 54(4): 729-752

Marchese, C. (2019) 'Tax Amnesty', in A. Marciano and G. Ramello, Encyclopedia of Law and Economics, Springer

Masiya, M. (2019) Lessons from Voluntary Compliance Window (VCW): Malawi's tax amnesty programme, CESifo Working Papers No. 7584

Mawejje, J. (2013) Tax Evasion, Informality and the Business Environment in Uganda, EPRC Research Series No. 113

Murphy, R. (2019) The European Tax Gap, retrieved from Socialists and Democrats Group in the European Parliament, www.socialistsanddemocrats.eu/sites/default/files/201901/the_european_tax_gap_en_190123.pdf

Musitwa, L. (2007) 'Ushs 3b Recovered from Tax Amnesty', 12 November 2007, retrieved 4 September 2020 from URN, https://ugandaradionetwork.net/story/ushs-3b-recoveredfrom-tax-amnesty 
Namibia Economist (2017) SECOND TAX AMNESTY IMPLEMENTATION TO COMMENCE, 5 September 2017, retrieved from https://economist.com.na/28088/headlines/secondtax-amnesty-implementation-to-commence/

OAG (2004) 2004 November Report of the Auditor General of Canada, retrieved from Office of the Auditor General of Canada: www.oag-

bvg.gc.ca/internet/English/parl_oag_200411_06_e_14910.html\#ch6hd4c

OCAC (2016) Report on the Voluntary Disclosures Program, retrieved from CRA, www.canada.ca/en/revenue-agency/programs/about-canada-revenue-agencycra/report-on-voluntary-disclosures-program.html

OECD (2019) Transparency and Exchange of Information for Tax Purposes: Multilateral Cooperation Changing the World 10th Anniversary Report, Paris: OECD Publishing

- (2015) Update on Voluntary Disclosure Programmes: A Pathway to Tax Compliance 2015, retrieved from OECD Publishing, www.oecd.org/ctp/exchange-of-taxinformation/Voluntary-Disclosure-Programmes-2015.pdf

- (2011) The Multilateral Convention on Mutual Administrative Assistance in Tax Matters, retrieved from OECD and Council of Europe, https://read.oecd-ilibrary.org/taxation/themultilateral-convention-on-mutual-administrative-assistance-in-taxmatters_9789264115606-en\#page3

Okoye, F. (2019) 'The influence of tax amnesty programme on tax compliance in Nigeria: The moderating role of political trust', Journal of Accounting and Taxation 11(7): 120129

Reyes-Tagle, G. and Ospina, L. (2020) 'Tax amnesties in times of COVID: Exceptional measures in exceptional times', 20 October 2020, retrieved from IDB's Fiscal Management Division, https://blogs.iadb.org/gestion-fiscal/en/tax-amnesties-in-timesof-covid-exceptional-measures-in-exceptional-times/

Ross, J. and Buckwalter, N. (2013) 'Strategic Tax Planning for State Tax Amnesties: Evidence from Eligibility Period Restrictions', Public Finance Review 41: 275-301

Stella, P. (1991) 'An economic analysis of tax amnesties', Journal of Public Economics 46(3): $383-400$

Sullivan, R. (2007) Statutory Interpretation, Irwin Law Inc.

The East African (2017) 'Uganda taxman, MTN back to court over tax dispute', 4 January 2017, retrieved from www.theeastafrican.co.ke/tea/business/uganda-taxman-mtn-backto-court-over-tax-dispute--1360128

The Independent (2020) 'URA commissioner general pledges to uproot corruption', 23 June 2020, retrieved from www.independent.co.ug/ura-commissioner-general-pledges-touproot-corruption/

(2019) 'Uganda introduces Digital Tax stamps to boost revenue', 1 November 2019, retrieved from www.independent.co.ug/uganda-introduces-digital-tax-stamps-to-boostrevenuel 
The Observer (2020a) 'I sacked corrupt URA crowd - Museveni', 11 June 2020, retrieved from https://observer.ug/news/headlines/65236-i-sacked-ura-corrupt-crowd-museveni

_ (2020b) 'URA's charm offensive great, but return what's due to Ugandans', 1 July 2020, retrieved from https://observer.ug/viewpoint/65481-ura-s-charm-offensive-great-butreturn-what-is-due-to-ugandans

Torgler, B. and Schaltegger, C. (2005) 'Tax amnesties and political participation', Public Finance Review 33(3) 403-31

UBOS (2018a)Manpower Survey Uganda (MAPU) 2016/2017, retrieved from Uganda Bureau of Statistics, www.ubos.org/wpcontent/uploads/publications/08_20182018_Uganda_Manpower_Survey_Report.pdf

_ (2018b) Uganda National Household Survey 2016/17, retrieved from Uganda Bureau of Statistics, www.ubos.org/wpcontent/uploads/publications/03_20182016_UNHS_FINAL_REPORT.pdf

UNECA (2019) Fiscal Policy for Financing Sustainable Development in Africa, retrieved from UNECA, https://repository.uneca.org/bitstream/handle/10855/41804/b11928190.pdf?sequence= 1 \&isAllowed=y

URA (2020a) Annual Revenue Performance Report FY 2019/2020, retrieved from www.ura.go.ug/openFile.do?path=//webupload//upload//download//staticContent//TOP MENU//9907//10192_RPR.pdf

(2020b) Introducing Digital Tax Stamps in Uganda, retrieved from https://ura.go.ug/Resources/webuploads/GNRART/Introducing\%20Digital\%20Tax\%20 Stamps.pdf

- (2020c) Public Notice: Voluntary Disclosure, 5 October 2020, retrieved from www.ura.go.ug/readMore.do?contentld=999000000001788\&type=TIMELINE

- (2019) Revenue Performance Report FY 2018/19, retrieved from Uganda Revenue Authority:

www.ura.go.ug/Resources/webuploads/GNRART/Revenue\%20Performance\%20Repor t\%20FY\%202018-19.pdf

_ (2007) Practice Note, 16 November 2007, General Notice No. 735 of 2007

Villalba, M. (2017) 'On the effects of repeated tax amnesties', Journal of Economics and Political Economy 4(3): 285-301

Wadesango, N., Mhaka, C., Bizah, S., Nyamwanza., L. and Haufiku, L. (2020) 'The Impact of Tax Amnesty on Tax Compliance and Tax Evasion Behavior among SMES', Academy of Entrepreneurship Journal 26(3): 1-10

Yucedogru, R. and Sarisoy, I. (2020) Are Tax Amnesties Good for Us All? Understanding Influence of Tax Amnesties on Benefiters and Non-Benefiters, CESifo Economic Studies 


\section{Local legislation}

Amnesty Act Cap 294

Finance Act No 2 of 1999

Finance Act, 2006

Finance Act, 2007

Finance Act, 2008

Finance Act, 2016

Limitation Act Cap 80

Tax Procedures Code Act, 2014

Judicature (Plea Bargain) Rules, 2016 available at

http://www.judiciary.go.ug/files/downloads/PleaBargainRules.pdf

\section{Foreign legislation}

Nigeria Executive Order No. 004 of 2017 available at https://nipc.gov.ng/ViewerJS/?\#../wpcontent/uploads/2019/03/EXECUTIVE-ORDER-4_2.pdf

Kenya Tax Procedures Act, 2015

South Africa Exchange Control Amnesty and Amendment of Taxation Laws Act No. 12

South Africa Final Relief on Tax, Interest, Penalty and Additional Tax Act No 101 of 1996

South Africa Small Business Tax Amnesty and Amendment of Taxation Laws Act No. 9 of 2006

South Africa Tax Administration Act 28 of 2011

Ghana Tax Amnesty Act 2017, (Act 955)

\section{Case Law}

\section{Uganda}

Begumisa v Tibebaga [2004] 2 EA 17

Kasibo v URA [2008] UGCOMMC 37

NSSF v URA High Court Civil Appeal No. 29 of 2020

URA v Remigious [2005] UGCOMMC 45

\section{Kenya}

Awal Limited $v$ Commissioner of Investigations and Enforcement Income Tax Appeal No.26 of 2017

\section{United States}

White $v$ United States, 194 F.2d. 215 (5th Cir. 1952)

Shotwell Mfg. Co. v United States, 371 U.S. 341 (1963)

Lapides v United States, 215 F.2d 253 (1954)

United States v Levy, 99 F. Supp. 529 (1951)

\section{Canada}

334156 Alberta Ltd v Canada (Minister of National Revenue), 2006 FC 1133

4053893 Canada Inc $v$ The Minister of National Revenue (2019) FC 51

AIMO v The Attorney General of Canada (2010) FC 1070

Charky v Attorney General of Canada (2010) FC 1327

CRA v Telfer, 2009 FCA 23

Karia $v$ Canada (Minister of National Revenue), 2005 FC 639

Palonek v The Minister of National Revenue (2007) FCA 281

Robinson v Her Majesty the Queen (2009) FC 795

Poon v Her Majesty the Queen (2009) FC 432 
Williams v The Minister of National Revenue (2011) FC 766

Worsfold $v$ The Minister of National Revenue (2012) FC 644

\section{South Africa}

Purveyors South Africa v SARS Case No: 61689/2019

India

Vikram v Union of India High Court of Delhi WP(C) 6268/2017 